\title{
Loont het investeren in het personeel?
}

Citation for published version (APA):

van Loo, J. B., \& de Grip, A. (2003). Loont het investeren in het personeel? Researchcentrum voor Onderwijs en Arbeidsmarkt, Faculteit der Economische Wetenschappen. ROA Reports No. 1 https://doi.org/10.26481/umarep.2003001

Document status and date:

Published: 01/01/2003

DOI:

10.26481/umarep.2003001

Document Version:

Publisher's PDF, also known as Version of record

\section{Please check the document version of this publication:}

- A submitted manuscript is the version of the article upon submission and before peer-review. There can be important differences between the submitted version and the official published version of record.

People interested in the research are advised to contact the author for the final version of the publication, or visit the DOI to the publisher's website.

- The final author version and the galley proof are versions of the publication after peer review.

- The final published version features the final layout of the paper including the volume, issue and page numbers.

Link to publication

\footnotetext{
General rights rights.

- You may freely distribute the URL identifying the publication in the public portal. please follow below link for the End User Agreement:

www.umlib.nl/taverne-license

Take down policy

If you believe that this document breaches copyright please contact us at:

repository@maastrichtuniversity.nl

providing details and we will investigate your claim.
}

Copyright and moral rights for the publications made accessible in the public portal are retained by the authors and/or other copyright owners and it is a condition of accessing publications that users recognise and abide by the legal requirements associated with these

- Users may download and print one copy of any publication from the public portal for the purpose of private study or research.

- You may not further distribute the material or use it for any profit-making activity or commercial gain

If the publication is distributed under the terms of Article $25 \mathrm{fa}$ of the Dutch Copyright Act, indicated by the "Taverne" license above, 


\section{Loont het investeren in het personeel?}

ROA-R-2003/1

Jasper van Loo

Andries de Grip

Researchcentrum voor Onderwijs en Arbeidsmarkt

Faculteit der Economische Wetenschappen en Bedrijfskunde Universiteit Maastricht

Maastricht, januari 2003 
Dit onderzoek is uitgevoerd in opdracht van het Ministerie van Economische Zaken

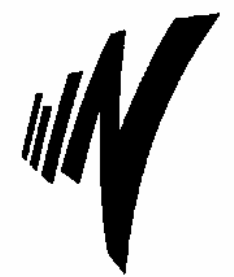

Ministerie van Economische Zaken

ISBN 90-5321-355-4

Sec02.147.doc 


\section{Inhoud}

Bladzijde

Voorwoord

Resumé

1 Inleiding 1

1.1 Inleiding 1

1.2 Opzet van dit rapport 2

2 Theoretisch kader 3

2.1 Inleiding 3

2.2 HRD: Wat is het? 4

2.3 Bedrijfsprestaties 5

2.4 De relatie tussen HRD en bedrijfsprestaties 6

$\begin{array}{ll}2.5 \text { Conclusies } & 7\end{array}$

3 HRD-beleid en opleidingsinspanningen bij Nederlandse bedrijven 9

$\begin{array}{ll}3.1 & \text { Inleiding }\end{array}$

3.2 Noodzaak tot het voeren van een HRD-beleid 10

3.3 Manieren om nieuwe kennis in huis te halen 11

$\begin{array}{lll}3.4 \text { HRD-instrumenten } & 12\end{array}$

3.5 Gebruikte opleidings- en ontwikkelingsinstrumenten $\quad 15$

$\begin{array}{ll}3.6 & \text { Soorten opleidingen } \\ 3.7 & 16\end{array}$

$\begin{array}{ll}3.7 & \text { Kosten van bedrijfsopleidingen } \\ 3.8 & 19\end{array}$

$\begin{array}{ll}3.8 \text { Enkele trends } & 19\end{array}$

$\begin{array}{ll}3.9 \text { Conclusies } & 21\end{array}$

4 De relatie tussen het HRD-beleid en de bedrijfsprestaties: de empirie 23

$\begin{array}{ll}4.1 \text { Inleiding } & 23\end{array}$

4.2 HRD-beleid en opleidingsinspanningen 23

4.3 De relatie tussen opleidingsinspanningen en bedriffsprestaties 26

4.4 De korte-termijn effecten van verschillende soorten opleidingen $\quad 35$

$\begin{array}{lll}4.5 & \text { Conclusies } & 37\end{array}$

$\begin{array}{ll}\text { Literatuur } & 39\end{array}$

Appendix: Statistische Analyses $\quad 41$ 



\section{Voorwoord}

Dit rapport gaat in op de vraag of het investeren in personeel loont bij Nederlandse ondernemingen. In het rapport wordt verslag gedaan van een empirisch onderzoek dat bij het CEREM van het Centraal Bureau voor de Statistiek (CBS) in Voorburg is uitgevoerd. Voor de actuele gegevens rondom het personeelsbeleid is er gebruik gemaakt van het integrale bestand van de Enquête Bedrijfsopleidingen 1999. Om de trends in het HRD-beleid zichtbaar te maken is wordt dit bestand gecombineerd met cijfers uit de Enquête Bedrijfsopleidingen 1993. Om de effecten van het personeelsbeleid op bedrijfsniveau te kunnen analyseren wordt gebruik gemaakt van een databestand dat gegevens uit de twee metingen van de Enquête Bedrijfsopleidingen combineert met twee jaargangen van de Productiestatistieken van het CBS. Dit laatste bestand moest om datatechnische redenen worden beperkt tot bedrijven in de sectoren industrie, groot- en detailhandel en bouwnijverheid.

De projectleiding van het onderzoek was in handen van prof. dr. A. de Grip. Drs. J.B. van Loo speelde een centrale rol bij de uitvoering van het onderzoek en de totstandkoming van de rapportage. De auteurs bedanken de leden van de begeleidingscommissie, drs. L. Brinkman, drs. A.M. van der Laag, drs. M.W. van Meerbeek en drs. T.W. Wong voor hun commentaar. Daarnaast bedanken de auteurs het CEREM voor het beschikbaar stellen van de gegevens die benodigd waren voor het uitvoeren van de statistische analyses in deze rapportage. Het spreekt voor zich dat de gevonden resultaten in dit rapport voor rekening zijn van de auteurs en dat ze niet noodzakelijkerwijs de opvattingen van het CBS en/of CEREM vertegenwoordigen. Een laatste woord van dank gaat uit naar de heer $C$. van Vroonhoven van CBS Heerlen, die een belangrijke rol speelde bij het aanleveren van gegevens die noodzakelijk waren voor het koppelen van de diverse databestanden. 



\section{Resumé}

De helft van de Nederlandse bedrijven is regelmatig genoodzaakt om nieuwe kennis en deskundigheid in huis te halen. De noodzakelijke kennisontwikkeling wordt voor het grootste deel bereikt door het opleiden van het al aanwezige personeelsbestand. Om deze opleidingsinspanningen te realiseren en in goede banen te leiden hebben veel bedrijven de beschikking over opleidingsplannen, -budgetten, interne opleidingscentra of andere opleidingsfaciliteiten. Deze aandacht voor de 'Human Resources' in bedrijven wordt weerspiegeld in het inmiddels grote aantal collectieve afspraken over opleiden, binnen dan wel buiten het raamwerk van CAO's.

Bedrijven kunnen op verschillende manieren in hun personeel investeren. In de literatuur wordt vaak een onderscheid gemaakt tussen het Human Resource Management (HRM) en het Human Resource Development (HRD). Het HRM omvat alle activiteiten van bedrijven die er op gericht zijn om een optimale inzet van het menselijk kapitaal te bereiken. Het HRD-beleid wordt vaak gezien als het onderdeel van het HRM beleid dat gericht is op het ontwikkelen van de competenties van het personeel. Tenslotte kan het opleidingsbeleid van organisaties gezien worden als de kern van het HRD dat er op gericht is de competenties van het personeel door middel van opleidingen te ontwikkelen.

In dit rapport richten we ons in het bijzonder op het Human Resource Development (HRD) beleid van bedrijven en het rendement van het opleidingsbeleid dat zich richt op het ontwikkelen van de competenties van het personeel. Daarbij gaat het om de volgende vijf vragen:

1. Wat is HRD, wat is de relatie met HRM en hoe kan het aan de bedrijfsprestaties gerelateerd worden?

2. Welke HRD-instrumenten worden er door het Nederlandse bedrijfsleven gebruikt en zijn er op dit punt verschillen tussen bedrijfssectoren of tussen grote bedrijven en het midden- en kleinbedrijf (MKB)?

3. Welke trends zijn er de laatste jaren op HRD gebied zichtbaar?

4. In welke mate stimuleert het gebruik van bepaalde HRD-instrumenten de deelname aan scholing van het personeel?

5. In welke mate is er bij bedrijven in Nederland een relatie tussen de deelname aan scholing en hun prestaties anderzijds, en in hoeverre is er daarbij sprake van een wederzijdse causaliteit tussen opleidingsinspanningen en prestaties?

\section{Human Resource Development en bedrijfsprestaties}

Human Resource Development (HRD) kan omschreven worden als alle activiteiten die erop gericht zijn het menselijk kapitaal binnen bedrijven te ontwikkelen. De opleidingsinspanningen kunnen gezien worden als de kern van het HRD beleid. In dit rapport worden de opleidingsinspanningen van een bedrijf gedefinieerd als de deelname van het personeel van een bedrijf aan interne en externe bedrijfsopleidingen. 
Het doel van vrijwel alle organisaties is het behalen van een bepaalde performance. Bedrijven streven in het algemeen primair naar zo goed mogelijke financiële prestaties, terwijl overheidsinstellingen en non-profit organisaties zaken als een zo groot mogelijke output, een optimale dienstverlening aan burgers of andere niet op winst gebaseerde doelstellingen nastreven. De bedrijfsprestaties kunnen op verschillende manieren gemeten worden. In dit rapport zullen drie prestatiemaatstaven worden gebruikt, te weten: de gemiddelde winst per medewerkers, de 'return on sales' (ROS) en de productiviteit. Deze laatste maatstaf wordt gemeten als de gemiddelde verkopen per medewerker.

De relatie tussen HRD enerzijds en bedrijfsprestaties anderzijds wordt geanalyseerd in twee stappen. In eerste instantie wordt gekeken naar het verband tussen het HRDbeleid en de opleidingsinspanningen. Vervolgens worden de opleidingsinspanningen gerelateerd aan de bedrijfsprestaties. Zeer belangrijk is ook de constatering dat niet alleen investeringen in het personeel de bedrijfsprestaties zou kunnen verbeteren, maar dat er ook sprake zou kunnen zijn van een omgedraaide causaliteit, bijvoorbeeld wanneer ondernemingen die goed presteren ook meer geld kunnen spenderen aan hun opleidingsinspanningen, of wanneer juist de bedrijven die minder goed presteren genoodzaakt zijn hun opleidingsbeleid te versterken.

\section{HRD-beleid en opleidingsinspanningen bij Nederlandse bedrijven}

Wanneer er gekeken wordt naar het huidige HRD-beleid blijkt dat de helft van de Nederlandse bedrijven aangeeft dat ze de om goed te kunnen functioneren doorlopend genoodzaakt zijn om nieuwe deskundigheid in huis te halen. In deze behoefte wordt meestal voorzien door het personeel dat al in dienst is op te leiden. Ter ondersteuning van het opleiden van de medewerkers heeft bijna een kwart van de bedrijven een opleidingsplan of -budget, maar tussen de verschillende bedrijfssectoren en bedrijven van verschillende grootten bestaan er op dit punt grote verschillen. Dit geldt ook voor het gebruik van eigen, interne opleidingscentra: de helft van de grootste bedrijven ( $>500$ werknemers) heeft de beschikking over een intern opleidingscentrum; bij de kleinere bedrijven (10-19 werknemers) geldt dat slechts voor $4 \%$ van de bedrijven.

Het meest gebruikte HRD-instrument is het extern opleiden. Bij de meeste externe opleidingen die het bedrijfsleven betreft het cursussen op het gebied van informatica, techniek en bouw of milieu en arbeidsomstandigheden. De totale opleidingsuitgaven van bedrijven verschillen sterk tussen de verschillende bedrijfssectoren. Zo wordt er bijvoorbeeld in het bank- en verzekeringswezen bijna vier maal zo veel per medewerker gespendeerd aan opleiden dan in de sector transport en communicatie.

Tussen 1993 en 1999 zijn er enkele trends in het HRD-beleid van bedrijven zichtbaar. Zo neemt in het algemeen het systematisch vaststellen van de competentiebehoefte van de organisatie en het hebben van opleidingsplannen en -budgetten af, terwijl het vaststellen van de behoeften van individuele werknemers juist toeneemt en ook meer bedrijven een eigen opleidingscentrum hebben. Toch zijn er 
tussen de verschillende bedrijfssectoren en -grootten ook duidelijke verschillen in de trends in het gebruik van HRM instrumenten te constateren.

\section{De relatie tussen het HRD en de bedrijfsprestaties}

De relatie tussen HRD en bedrijfsprestaties wordt in dit rapport geanalyseerd door gebruik te maken van een tweestapsmodel. In de eerste stap wordt het HRD-beleid, gemeten door het gebruik van bepaalde HRD-instrumenten gerelateerd aan de opleidingsdeelname. In de tweede stap wordt de deelname aan bedrijfsopleidingen in verband gebracht met de prestaties van een bedrijf.

Voor wat betreft de eerste stap kunnen de volgende conclusies getrokken worden: Bepaalde instrumenten van het HRD-beleid, zoals bijvoorbeeld het hebben van een opleidingsplan, blijken de deelname van de medewerkers aan interne en externe bedrijfsopleidingen positief te beïnvloeden. Wanneer bedrijven een eigen opleidingscentrum hebben zorgt dit voor een sterke stimulans van de deelname aan interne bedrijfsopleidingen. Wanneer bedrijven beschikken over een opleidingsbudget stimuleert dit de deelname aan externe opleidingen. Dit geldt ook voor het hebben van collectieve opleidingsafspraken binnen het raamwerk van CAO's of daarbuiten. Deze HRD-instrumenten zijn dus effectief in de zin dat ze de opleidingsdeelname van de medewerkers bevorderen. De cijfermatige uitkomsten van de analyses in de eerste stap worden in het kader hieronder kort weergegeven. De volledige analyses zijn terug te vinden in hoofdstuk 4 van het rapport.

\begin{tabular}{|lll|}
\hline \multicolumn{2}{|c|}{ Instrumenten uit het HRM beleid en opleidingsparticipatie } \\
& $\begin{array}{l}\text { Neemt het gemiddeld aantal } \\
\text { opleidingen per }\end{array}$ & Eerknemer toe met: \\
Wanneer bedrijven: & Interne & Externe \\
& Opleidingen & Opleidingen \\
& & - \\
Systematisch opleidingsbehoeften vaststellen & 0,015 & 0,101 \\
Systematisch behoefte werknemers vaststellen & 0,079 & 0,139 \\
Beschikken over een opleidingsbudget & 0,043 & 0,065 \\
Beschikken over een opleidingsplan & 0,124 & - \\
Beschikken over een opleidingscentrum & 0,431 & 0,143 \\
Collectieve opleidingsafspraken hebben & 0,065 & \\
& & \\
\end{tabular}

De tweede stap gaat in op de vraag of de scholingsdeelname van het personeel effecten heeft op de bedrijfsprestaties. Op deze manier is onderzocht in welke mate scholing ook op financieel gebied op langere termijn loont. Met behulp van een panelbestand van Nederlandse bedrijven (>10 werknemers) worden de opleidingsinspanningen gerelateerd aan de bedrijfsprestaties. Daarbij is geen rekening gehouden met de duur en de inhoud van de verschillende opleidingen. De bedrijfsprestaties worden op drie verschillende manieren gemeten, te weten: de winst per 
medewerker, de 'return on sales' en de gemiddelde productiviteit per werknemer, gemeten door de gemiddelde verkopen per medewerker. Uit de analyses blijkt dat voor alle gebruikte prestatiemaatstaven, de bedrijfsprestaties duidelijk samenhangen met de opleidingsinspanningen. Uit de analyses blijkt dat wanneer het gemiddeld aantal cursussen per medewerker met één stijgt, de gemiddelde winst per medewerker met rond de $€ 12.500$ toeneemt terwijl de productiviteit met ongeveer $€ 57.000$ stijgt. De return on sales blijkt bij een dergelijke toename in cursusdeelname met rond de $0,37 \%$ toe te nemen. De belangrijkste resultaten worden nog eens kort samengevat in het kader hieronder:

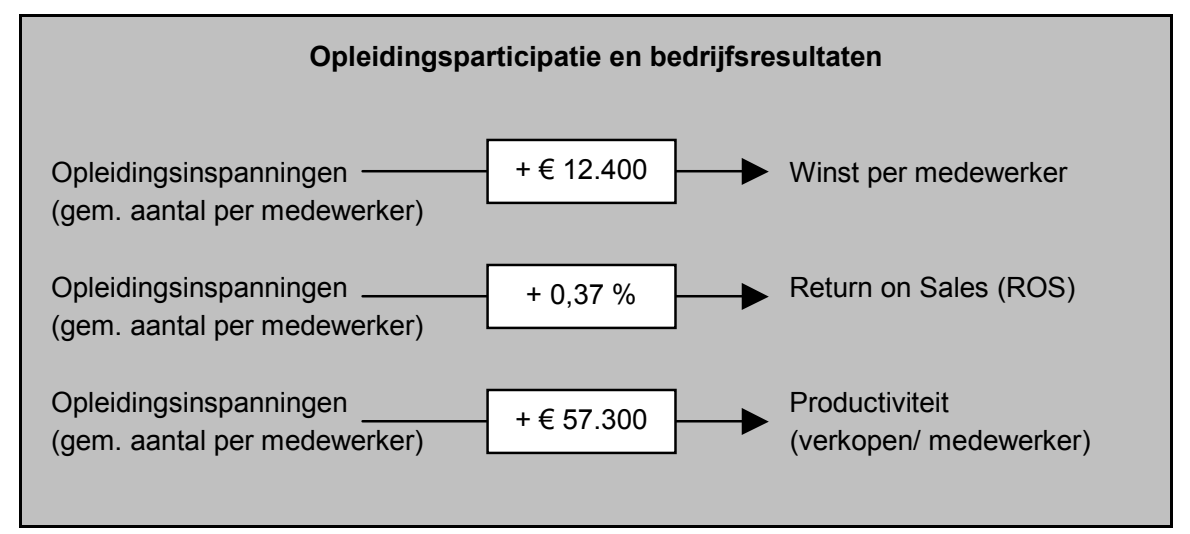

Daarnaast blijkt dat er ook sprake is van een omgekeerde relatie tussen bedrijfsprestaties en opleidingsinspanningen. Een verklaring hiervoor zou kunnen zijn dat goed presterende bedrijven eenvoudigweg meer middelen ter beschikking hebben om het opleiden van hun personeel te bekostigen. Het gevonden effect is echter een stuk minder sterk dan de invloed van opleidingsinspanningen op de bedrijfsprestaties.

Als laatste is er in dit rapport gekeken naar de korte termijn opbrengsten van bepaalde soorten opleidingen. Sommige soorten opleidingen blijken een direct positief effect te hebben op de prestaties van bedrijven, terwijl voor andere soorten opleidingen geldt dat de investeringen de opbrengsten op de korte termijn overstijgen. Opleidingen op het gebied van talen, management en techniek hebben een direct en positief effect op de bedrijfsprestaties. Informatica- en verkoop en marketingopleidingen beïnvloeden de resultaten daarentegen op de korte termijn juist negatief. Dit houdt overigens niet in dat het niet lonend zou zijn om in dergelijke opleidingen te investeren. Veel van de opbrengsten van bedrijfsopleidingen manifesteren zich immers pas op de langere termijn.

Het belangrijkste resultaat uit dit onderzoek is dat er sprake lijkt te zijn van zowel een verband tussen HRD-beleid en opleidingsinspanningen als ook van een wisselwerking tussen opleidingsinspanningen en bedrijfsprestaties. Dit impliceert dat opleiden een zichzelf versterkend proces te weeg brengt dat de bedrijfsprestaties ten goede komt. Het investeren in de competenties van het personeel brengt daardoor een lonend proces op gang. 


\section{Inleiding}

\subsection{Inleiding}

Het Human Resource Management (HRM) wordt de laatste jaren steeds meer gezien als een beslissende factor voor bedrijfsprestaties. Een aantal verschillende trends zorgt ervoor dat er een verschuiving heeft plaatsgevonden van een HRM beleid dat zich richt op training en development naar een HRM dat de prestaties van mensen in organisaties op een meer integrale manier probeert te benaderen en verbeteren (Rothwell, 1996). Dit houdt in dat naast de ontwikkeling van werkenden ook andere factoren die het functioneren van mensen in organisaties beïnvloeden aan de orde komen. Hierbij kan bijvoorbeeld gedacht worden aan het 'kennismanagement', waarin de allocatie van de in een organisatie aanwezige kennis centraal staat in het HRM een plaats hebben gekregen. Bovendien raakt met name in grote organisaties het HRM-beleid steeds meer verweven met het strategisch beleid.

Een belangrijke pijler in het HRM beleid vormt het zogenaamde Human Resource Development (HRD). Het HRD, en het daaraan gerelateerde opleidingsbeleid van bedrijven staat centraal in dit rapport. Hoewel veel bedrijven te maken hebben met de snelle veranderingen die zich in de laatste tientallen jaren hebben voorgedaan, zijn het met name de grote organisaties waar het HRD zich het snelst ontwikkelt. Bij kleinere bedrijven lijkt het soms niet mogelijk om een HRD-beleid te voeren, omdat de middelen er eenvoudigweg voor ontbreken, of omdat men eenvoudigweg geen tijd heeft om zich hierin te verdiepen (Erickson \& Jacoby, 2002). Wat hierbij ook een rol speelt zijn mogelijke schaalvoordelen. Grotere bedrijven kunnen, doordat er in de organisatie specifieke functies gecreëerd zijn om het HRD-beleid te ontwikkelen en uit te voeren (de personeelsfunctionarissen) en er bovendien vaak sprake is van een koppeling tussen HRD en het strategisch beleid, waarschijnlijk makkelijker initiatieven nemen op het gebied van het HRD-beleid en de uitvoering daarvan. De koppeling tussen het HRD en het strategisch beleid vergroot ook de effectiviteit van het HRM-beleid (Rothwell, 1996).

Het lijkt erop, bijvoorbeeld wanneer gekeken wordt naar de lage opleidingsinspanningen bij de kleinere bedrijven (ROA, 2000), dat met name de kleinere en de middelgrote bedrijven zich te weinig bewust zijn van de voordelen van HRD-beleid, terwijl ze wel de kosten daarvan zien. Twijfel over het (verder) ontwikkelen van een HRD-beleid komt dan ook vaak voort uit de vraag of dat beleid wel loont. Om een gedegen kosten-baten analyse te kunnen maken is er echter informatie nodig over de opbrengsten en kosten van het HRD-beleid (Swanson, 2001). Omdat zowel kosten en baten in voor een bepaald bedrijf vaak tevoren erg moeilijk in te schatten zijn, of sterk beïnvloed kunnen worden door onzekere factoren, kan informatie over 
de effectiviteit van bepaalde HRD-instrumenten bij andere bedrijven gezien worden als een hulpmiddel voor bedrijven om de HRD-beleidsbeslissingen te ondersteunen. ${ }^{1}$

\subsection{Opzet van dit rapport}

In dit rapport wordt de effectiviteit van HRD in Nederlandse ondernemingen empirisch onderzocht. Daarbij richten we ons in het bijzonder op het opleidingsbeleid binnen bedrijven. De centrale vragen die in dit rapport aan de orde komen zijn de volgende:

1. Wat is HRD, wat is de relatie met HRM en hoe kan het aan de bedrijfsprestaties gerelateerd worden?

2. Welke HRD-instrumenten worden er door het Nederlandse bedrijfsleven gebruikt en zijn er op dit punt verschillen tussen bedrijfssectoren of tussen grote bedrijven en het midden- en kleinbedrijf (MKB)?

3. Welke trends zijn er de laatste jaren op HRD gebied zichtbaar?

4. In welke mate stimuleert het gebruik van bepaalde HRD-instrumenten de deelname aan scholing van het personeel?

5. In welke mate is er bij bedrijven in Nederland een relatie tussen de deelname aan scholing en hun prestaties anderzijds, en in hoeverre is er daarbij sprake van een wederzijdse causaliteit tussen opleidingsinspanningen en prestaties?

Het rapport zal als volgt worden opgebouwd: In hoofdstuk 2 wordt kort het theoretisch kader geschetst dat we gebruiken in dit rapport en wordt er een overzicht gegeven van de definities die we hanteren. In hoofdstuk 3 wordt er vervolgens een overzicht gegeven van het HRD-beleid in Nederlandse bedrijven door te kijken naar het gebruik van diverse HRD-instrumenten. Ook de opleidingsinspanningen komen in dit hoofdstuk uitgebreid aan de orde. Er wordt telkens aangegeven in hoeverre het HRD-beleid en de opleidingsinspanningen uiteenlopen tussen bedrijfssectoren en tussen grote bedrijven en het midden- en kleinbedrijf (MKB). Ook de trends die er de laatste jaren zichtbaar zijn in het HRD-beleid in Nederlandse bedrijven komen in dit hoofdstuk kort aan de orde. In hoofdstuk 4 wordt ingegaan op de kernvraag van dit rapport. In dit hoofdstuk worden drie empirische analyses gepresenteerd. In de eerste analyse wordt de relatie tussen het gebruik van bepaalde HRD-instrumenten en de deelname aan opleidingen onderzocht. Vervolgens wordt in de tweede analyse de effectiviteit van opleidingsinspanningen onderzocht door te kijken naar de relatie tussen opleiden en de bedrijfsprestaties van het bedrijf. In de laatste analyse wordt er tenslotte gekeken naar de korte-termijn opbrengsten van verschillende soorten bedrijfsscholing. In dit hoofdstuk wordt verder geprobeerd de empirie aan de literatuur te staven door een mogelijke interpretatie van de gevonden resultaten te geven.

1. Erickson \& Jacoby (2002) wijzen in dit verband ook op het belang van informatie-overdracht binnen de diverse netwerken waar bedrijven zich bij aansluiten (brancheverenigingen, professionele netwerken, samenwerkingsverbanden e.d.). 


\section{Theoretisch kader}

\subsection{Inleiding}

In het Nederlandse bedrijfsleven staat het Human Resource Development momenteel volop in de belangstelling. Aangezien het besef steeds meer doordringt dat in de huidige kenniseconomie het menselijk kapitaal in het productieproces veelal de doorslaggevende factor is voor de productiviteit, ontstaat de laatste jaren met name een groeiende aandacht voor het opleidings- en ontwikkelingsbeleid. Dit beleid heeft veelal als hoofddoelstelling het menselijk kapitaal van werknemers geschikt te houden c.q. te maken voor zowel de huidige als ook de toekomstige eisen van de arbeidsmarkt.

Goed personeelsbeleid staat de laatste jaren steeds meer in de belangstelling en is in veel bedrijven een integraal onderdeel van het strategisch beleid geworden. Deze toenemende belangstelling valt met name te verklaren door een aantal ontwikkelingen die er in het werk, in de bedrijven en in de omgeving van bedrijven hebben plaatsgevonden. Een aantal belangrijke oorzaken zijn de volgende:

- Een toenemend gebruik van Informatie en Communicatie Technologie (ICT).

- Ingrijpende organisatorische veranderingen in veel organisaties, ook als een reactie op het toenemende gebruik van ICT.

- Het toenemende belang van de kwaliteit van de dienstverlening. Steeds vaker eisen consumenten op hun behoeften toegespitst maatwerk van een goede kwaliteit. Dit heeft tot gevolg dat concepten als ISO-certificering en Total Quality Management (TQM) in veel organisaties inmiddels gemeengoed zijn geworden.

- De mondialisering en liberalisering van afzetmarkten die tot gevolg heeft gehad dat de concurrentie heviger is geworden, zowel tussen bedrijven op de Nederlandse markt als ook op de exportmarkten van het Nederlandse bedrijfsleven. Dit heeft ook geleid tot een sterkere nadruk op de concurrentie op 'core-business' activiteiten van ondernemingen.

Deze ontwikkelingen vragen om breed inzetbaar en goed opgeleid personeel dat zich makkelijk aan veranderingen binnen en buiten bedrijven aanpast en daarop inspeelt. Conclusie: HRD-beleid wordt belangrijker om goed te kunnen presteren.

In dit hoofdstuk wordt in paragraaf 2.2 allereerst een overzicht gegeven van wat HRD precies inhoudt en welke relatie er met het bredere vakgebied Human Resource Management (HRM) bestaat. In paragraaf 2.3 wordt vervolgens ingegaan op de manier waarop in dit rapport de bedrijfsprestaties gemeten worden. De relatie tussen HRD en de bedrijfsprestaties komt in paragraaf 2.4 aan de orde. Paragraaf 2.5 sluit dit hoofdstuk af met enkele conclusies. 


\subsection{HRD: Wat is het?}

Omdat het Human Resource Development (HRD) sterk verweven is met het bredere vakgebied van het Human Resource Management (HRM) is het van belang om eerst de relatie tussen deze twee vakgebieden aan te geven. HRD kan gezien worden als een onderdeel van het HRM. HRM kan omschreven worden als "een visie op personeel volgens welke de ontwikkeling van het 'menselijk potentieel' van strategische waarde is voor de overlevingskansen van een bedrijfskundige eenheid" (Thijssen, 1997). Het HRM kan beschouwd worden als een bedrijfskundige benadering die past bij dynamische organisaties die op concurrerende markten actief zijn, maar het is tot nu toe nog niet een duidelijk omschreven concept. Bovendien zijn er verschillende vormen van HRM in de literatuur te vinden. In de literatuur van het groeiende vakgebied HRM, dat zich heeft ontwikkeld vanuit het klassieke personeelsmanagement, worden verschillende opsommingen gegeven over de onderdelen die er deel van uit maken.

Vanuit een economisch perspectief is het mogelijk te komen tot een werkdefinitie van HRM. Wanneer het menselijk kapitaal vanuit de 'resource based theory of the firm' gezien wordt als een bron van comparatief voordeel waarmee economische waarde kan worden gecreëerd, kan het HRM gedefinieerd worden als alle activiteiten die erop gericht zijn het menselijk kapitaal binnen organisaties aan te trekken, op peil te houden, te ontwikkelen en op effectieve wijze in te zetten.

\section{Definitie HRM}

Human Resource Management (HRM) omvat alle activiteiten die erop gericht zijn het menselijk kapitaal binnen bedrijven aan te trekken, op peil te houden, te ontwikkelen en op effectieve wijze in te zetten.

Vanuit economisch perspectief kunnen er in binnen het Human Resource Management twee hoofdonderdelen onderscheiden worden: HRM gericht op het niveau van de in een bedrijf aanwezige Human Resources en HRM gericht op de allocatie van het menselijk kapitaal. ${ }^{2}$

Het HRD kan gezien worden als een onderdeel van het HRM dat gericht is op het niveau van het menselijk kapitaal van het personeel van bedrijven. Het omvat alle activiteiten die binnen bedrijven worden ondernomen om het menselijk kapitaal van het personeel te ontwikkelen.

\section{Definitie HRD}

Human Resource Development (HRD) omvat alle activiteiten die erop gericht zijn het menselijk kapitaal binnen bedrijven te ontwikkelen.

2. In het rapport Loont HRM, Een literatuurverkenning, wordt hierop dieper ingegaan. 
De opleidingsinspanningen van bedrijven kunnen gezien worden als de kern van het HRD-beleid. De opleidinginspanning van bedrijven wordt in dit rapport gedefinieerd als de deelname van het personeel aan in- en externe bedrijfsopleidingen.

Definitie Opleidingsinspanningen

De deelname van het personeel van een bedrijf aan interne en externe bedrijfsopleidingen.

\subsection{Bedrijfsprestaties}

Het doel van vrijwel alle organisaties is het behalen van een bepaalde performance. Bedrijven streven in het algemeen primair naar zo goed mogelijke financiële prestaties, terwijl overheidsinstellingen en non-profit organisaties zaken als een zo groot mogelijke output, een optimale dienstverlening aan burgers of andere niet op winst gebaseerde doelstellingen nastreven.

In dit rapport zullen de prestaties van bedrijven op een aantal verschillende manieren worden gemeten. Achtereenvolgens wordt gekeken naar de volgende indicatoren. ${ }^{3}$ In de eerste plaats wordt gekeken naar de gemaakte winst per medewerker. Hierbij gaat het om de totale winst voor belastingen in een bepaald kalenderjaar gedeeld door het totaal aantal werknemers aan het eind van het jaar.

Daarnaast worden de prestaties van een bedrijf geïndiceerd door de Return on sales (ROS). Dit is een maatstaf die de winst relateert aan de verkopen van een organisatie. De maatstaf wordt in het algemeen gedefinieerd als de winst gedeeld door de waarde van de verkopen. Net als bij de andere statische financiële maatstaven is het nadeel van deze indicator dat ze slechts een momentopname van de financiële situatie van een organisatie geeft. Daarnaast geeft de ROS geen indicatie voor de mate waarin het bedrijfsvermogen rendeert. Het voordeel van het gebruik van de ROS is dat ze goed meetbaar is zonder dat er schattingen van het geïnvesteerde vermogen in een bedrijf gemaakt hoeven te worden.

Ten slotte wordt gekeken naar de gemiddelde (arbeids)productiviteit per werknemers. Dit is een belangrijke indicator voor de bedrijfsprestaties omdat het een maatstaf is voor de effectiviteit waarmee werknemers met de door een organisatie ter beschikking gestelde kapitaalgoederen output (producten en diensten) produceren. Het voordeel van deze indicator is dat ze relatief ongevoelig is voor schommelingen op de kapitaal- en afzetmarkt (Huselid et al., 1997). Het nadeel van het gebruik van productiviteit als prestatiemaatstaf is dat de kosten van de organisatie niet worden meegenomen.

3. Zie van Loo en De Grip (2002, hoofdstuk 3) van een uitvoerig overzicht van performance indicatoren. 


\section{Prestatiemaatstaven}

Om de prestaties van bedrijven te meten wordt er in dit rapport gebruik gemaakt van een drietal prestatiemaatstaven, te weten:

1. De gemiddelde winst per medewerker;

2. De 'return on sales' (ROS);

3. De gemiddelde arbeidsproductiviteit, gemeten door de gemiddelde verkopen per medewerker.

\subsection{De relatie tussen HRD en bedrijfsprestaties}

Een belangrijk thema in het HRD is het aantonen van een causaal verband tussen het HRD-beleid enerzijds en de opbrengsten daarvan anderzijds. Een centrale veronderstelling in de literatuur en ook in dit rapport is dat de relatie tussen het HRDbeleid en de bedrijfsprestaties in twee stappen geanalyseerd moet worden (Paauwe \& Richardson, 1997). Er wordt vanuit gegaan dat het HRD-beleid de opleidingsinspanningen beïnvloedt. De opleidingsinspanningen hebben vervolgens invloed hebben op de bedrijfsprestaties.

Het theoretisch kader dat we in dit rapport gebruiken laat zich goed samenvatten in een schematisch model. Dit model, dat gebaseerd is op de genoemde tweestapsrelatie tussen HRD-beleid en bedrijfsresultaten, wordt gepresenteerd in figuur 2.1.

Figuur 2.1

De relatie tussen HRD-beleid, opleidingsinspanningen en bedrijfsprestaties

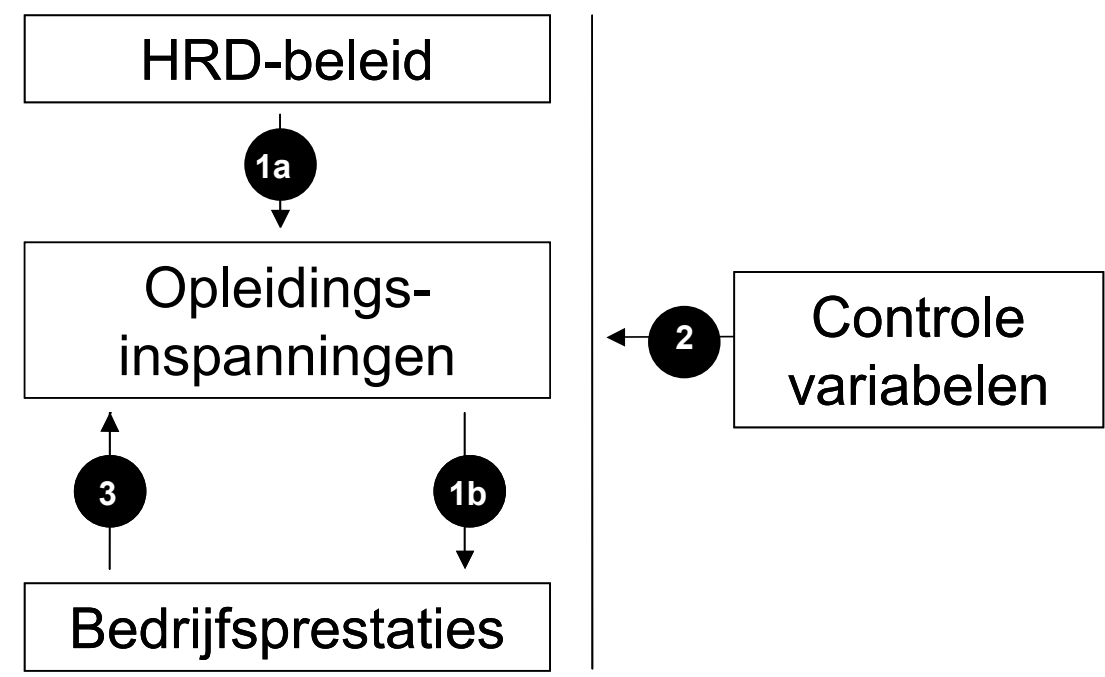


De relaties in het afgebeelde model zijn genummerd. Relatie 1a gaat in op het verband tussen het HRD-beleid en de opleidingsinspanningen. Een voorbeeld van deze relatie is het verband het hebben van bepaalde opleidingsfaciliteiten, zoals bijvoorbeeld een opleidingsbudget en de deelname aan bedrijfsopleidingen. Relatie $1 \mathrm{~b}$ geeft de relatie tussen opleidingsinspanningen en de bedrijfsprestaties weer.

Daarnaast zijn er een aantal controlevariabelen (bedrijfskenmerken e.d.) die de verschillende variabelen en relaties kunnen beïnvloeden (relatie 2). Ten slotte kan er sprake zijn van een omgedraaide causaliteit (relatie 3). Daarbij hebben de prestaties van de organisatie een 'feedback' naar de opleidingsinspanningen, bijvoorbeeld wanneer ondernemingen die goed presteren ook meer geld kunnen spenderen aan het opleiden van het personeel, of wanneer juist de bedrijven die minder goed presteren genoodzaakt zijn hun opleidingsinspanningen te vergroten (Zwick, 2002).

\subsection{Conclusies}

De toenemende belangstelling voor een goed personeelsbeleid valt met name te verklaren door een aantal ontwikkelingen die er in het werk, in de bedrijven en in de omgeving van bedrijven hebben plaatsgevonden. Ontwikkelingen op het gebied van ICT, organisatie, kwaliteit en concurrentie hebben er voor gezorgd dat de behoefte aan flexibiliteit in bedrijven de laatste decennia steeds groter is geworden. Ze vragen om breed inzetbaar en goed opgeleid personeel dat zich makkelijk aan veranderingen binnen en buiten bedrijven aanpast en daarop inspeelt. Vandaar dat het HRDbeleid in veel bedrijven een integraal onderdeel van het strategisch beleid is geworden.

In dit hoofdstuk wordt in eerste instantie aangegeven wat HRD precies inhoudt en welke relatie er met het bredere gebied Human Resource Management (HRM) bestaat. HRD kan vervolgens omschreven worden als alle activiteiten die erop gericht zijn het menselijk kapitaal binnen bedrijven verder te ontwikkelen. De opleidingsinspanningen kunnen gezien worden als de kern van het HRM beleid. Ze worden in dit rapport gedefinieerd als de deelname van het personeel van een bedrijf aan interne en externe bedrijfsopleidingen.

In de daarop volgende paragraaf wordt de wijze waarop in dit rapport de bedrijfsprestaties gemeten worden besproken. In de analyses zullen drie prestatiemaatstaven worden gebruikt, te weten: de gemiddelde winst per medewerkers, de 'return on sales' (ROS) en de productiviteit. Deze laatste maatstaf wordt gemeten als de gemiddelde verkopen per medewerker.

Tenslotte wordt ingegaan op de mogelijke relaties tussen HRD en de bedrijfsprestaties. Daarbij wordt de methodiek die in het vervolg van dit rapport gebruikt wordt besproken. De relatie tussen HRD-beleid enerzijds en bedrijfsprestaties anderzijds wordt geanalyseerd in twee stappen. In eerste instantie wordt gekeken naar het verband tussen het HRD-beleid en de opleidingsinspanningen. Vervolgens worden de opleidingsinspanningen gerelateerd aan de bedrijfsprestaties. Zeer belangrijk is ook de constatering dat niet alleen investeringen in het personeel de 
bedrijfsprestaties zou kunnen verbeteren, maar dat er ook sprake zou kunnen zijn van een omgedraaide causaliteit, bijvoorbeeld wanneer ondernemingen die goed presteren ook meer geld kunnen spenderen aan hun opleidingsinspanningen, of wanneer juist de bedrijven die minder goed presteren genoodzaakt zijn hun opleidingsbeleid te versterken (Zwick, 2002). 


\section{HRD-beleid en opleidingsinspanningen bij Nederlandse bedrijven}

\subsection{Inleiding}

Uit de praktijk blijkt dat het HRD niet universeel wordt toegepast in het Nederlandse bedrijfsleven. Uit onderzoek van TNO Arbeid komt naar voren dat het gebruik van bepaalde HRD-instrumenten sterk samenhangt met de organisatiegrootte (Willemsen et al., 2000). Ook uit ander empirisch onderzoek komt naar voren dat bijvoorbeeld bedrijven in het MKB steevast minder aandacht besteden aan het opleiden van het personeel dan grote bedrijven.

Een gedeelte van de behoefte aan Human Resource Development komt voort uit de specifieke situatie waarin een bedrijf zich bevindt. Zo zal het opleidingsbeleid in bedrijven die concurreren in een hoogtechnologische markt (zoals bijvoorbeeld de ICT-sector) belangrijker zijn als in bedrijven die actief zijn in markten waar technologische ontwikkelingen een minder prominente rol spelen.

Echter, een deel van de verschillen tussen bedrijven wat betreft het gevoerde HRDbeleid komt wellicht ook voort uit het feit dat bepaalde bedrijven de voordelen van een goed HRD-beleid onvoldoende onderkennen. Met name bij bedrijven uit het MKB blijkt dat het er vaak nogal wat overredingskracht noodzakelijk is om werkgevers van het nut van een goed HRD-beleid te overtuigen. Uit onderzoek van Erickson \& Jacoby (2002) komt naar voren dat dit mede het gevolg is van het feit dat het midden- en kleinbedrijf minder participeert in netwerken waarin ze zich op de hoogte kunnen stellen van bepaalde 'best practices' op HRD gebied en de voordelen die het invoeren van dit HRD voor het bedrijf kan hebben. ${ }^{4}$

In dit hoofdstuk wordt een overzicht gegeven van de mate waarin er in het Nederlandse bedrijfsleven gebruik gemaakt wordt van HRD-beleid en wordt er gekeken naar de opleidingsinspanningen binnen bedrijven. Het HRD-beleid wordt in beeld gebracht door te kijken naar de mate waarin bedrijven HRD-instrumenten gericht op het opleiden van hun personeel, zoals bijvoorbeeld het hebben van opleidingsplannen en -budgetten, gebruiken. De opleidingsinspanningen worden onderzocht door te kijken naar de mate waarin werknemers in- en externe opleidingen volgen. In het volgende hoofdstuk komt de effectiviteit van het HRDbeleid aan bod.

De gegevens die in dit hoofdstuk worden gepresenteerd zijn afkomstig van de Enquête Bedrijfsopleidingen 1999. Deze enquête werd door het CBS uitgevoerd en

4. Ook speelt bij bepaalde bedrijven de vrees dat bij een goed HRD-beleid, dat gericht is op het verbeteren van de employability van de werknemers, het personeelsverloop zal toenemen, omdat deze werknemers aantrekkelijker worden voor de externe arbeidsmarkt. Wel wordt dan vaak vergeten dat een goed HRD-beleid ook de wervingskracht van een bedrijf kan vergroten en tegelijkertijd de werknemers die bij het bedrijf in dienst zijn beter zal 'binden en boeien' (zie bv. De Grip en Sieben, 2001). 
geeft een beeld van de scholingsinspanningen bij bedrijven met 10 werknemers of meer. De gegevens zullen telkens zowel naar bedrijfssector als naar bedrijfsgrootte worden verbijzonderd. Op deze wijze wordt duidelijk welke verschillen er tussen de bedrijfssectoren bestaan op het gebied van het gevoerde HRD-beleid en opleidingsinspanningen en kunnen bovendien eventuele verschillen tussen kleinere en grote bedrijven zichtbaar gemaakt worden.

De opzet van dit hoofdstuk is als volgt: In paragraaf 3.2 wordt er gekeken naar de noodzaak tot het voeren van een HRD-beleid. Paragraaf 3.3 gaat vervolgens in op de manieren waarop bedrijven de benodigde kennis in huis halen. In paragraaf 3.4 wordt er gekeken naar de instrumenten in het HRM-beleid van bedrijven, zoals bijvoorbeeld het hebben van een opleidingsplan of -budget. Paragraaf 3.5 gaat vervolgens in op de gebruikte opleidings- en ontwikkelingsinstrumenten. Paragraaf 3.6 gaat in op de soorten bedrijfsopleidingen die in het Nederlandse bedrijfsleven worden gevolgd. De kosten van bedrijfsopleidingen worden besproken in paragraaf 3.7. Enkele trends komen aan de orde in paragraaf 3.8. Paragraaf 3.9 sluit het hoofdstuk af door de belangrijkste uitkomsten nog eens op een rij te zetten.

Tabel 3.1

Percentage bedrijven dat genoodzaakt is om nieuwe kennis en deskundigheid in huis te halen, 1997-1999

$\begin{array}{ll}\text { Bedrijfssector/bedrijfsgrootte } & \%\end{array}$

Bedrijfssector

Voeding

Chemie

Metaal en elektrotechniek

Overige industrie

Energie

Bouw en onroerend goed

Handel en reparatie

Transport en communicatie

Bank en verzekeringswezen

Horeca en zakelijke dienstverlening

Kwartaire diensten

Bedrijfsgrootte

10-19 werknemers

20-99 werknemers

100-499 werknemers

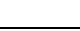

meer dan 500 werknemers

Totaal

Bron: CBS (Enquête bedrijfsopleidingen)/ ROA

\subsection{Noodzaak tot het voeren van een HRD-beleid}

Bedrijven zullen, naarmate de afzetmarkten waarop zij hun producten en diensten aanbieden en veranderingen in technologie en organisatie dat vragen, behoefte hebben aan nieuwe of andere kwalificaties van hun personeel (zie bijvoorbeeld De 
Grip, 2001; Green et al., 2000). In tabel 3.1 wordt een beeld geschetst van de mate waarin bedrijven zich genoodzaakt voelen om nieuwe kennis in huis te halen.

De tabel laat in eerste instantie zien dat de helft van de bedrijven behoefte heeft aan nieuwe kennis. Uit de tabel komt verder naar voren dat de grootste behoefte aan nieuwe kennis en deskundigheid zich voordoet in de sectoren bank en verzekeringswezen en chemie. In de sectoren bouw en onroerend goed en transport en communicatie is deze behoefte daarentegen het kleinst. Ook blijkt dat de behoefte aan nieuwe kennis en vaardigheden positief gerelateerd is aan de bedrijfsgrootte. In kleine bedrijven (10-19 werknemers) heeft slechts $40 \%$ van de bedrijven deze behoefte; voor grote ondernemingen ( $>500$ werknemers) is dit percentage maar liefst $86 \%$.

\subsection{Manieren om nieuwe kennis in huis te halen}

Ondernemingen kunnen de benodigde nieuwe kennis en vaardigheden op verschillende manieren in huis halen. Tabel 3.2 geeft een overzicht van zes manieren waarop bedrijven aangeven dit te doen: 1) werknemers laten leren via werkervaring ('ervaring'); 2) werknemers opleidingen of trainingen laten volgen ('training'); 3) jongere leerlingen of stagiaires opleiding en training geven ('jongeren'); 4) werklozen in dienst nemen en opleiden ('werklozen'); 5) ongeschoolden in dienst nemen en opleiden ('ongeschoolden') of 6) werknemers in dienst nemen die al over benodigde kennis en vaardigheden beschikken ('gekwalificeerden').

Tabel 3.2 laat zien dat opleiding en training van het personeel de meest gebruikte methode is om de benodigde kennis en vaardigheden in huis te halen. lets minder dan de helft van de bedrijven geeft aan dat het benodigde menselijk kapitaal ook via werkervaring kan worden aangeleerd. Er bestaan echter ook nog een aantal externe opties om de benodigde kwalificaties te verkrijgen. Zo geeft $49 \%$ van de bedrijven aan dat ze werknemers die de benodigde kennis bezitten werven op de externe arbeidsmarkt. De drie minst gebruikte opties zijn het in dienst nemen van jongeren als stagiaires, werklozen en ongeschoolde arbeidskrachten.

Wanneer gekeken wordt naar de verschillen tussen bedrijfssectoren en bedrijfsgroottes, blijkt dat in de sectoren transport en communicatie en kwartaire diensten relatief weinig deskundigheid wordt opgebouwd doordat de werkenden meer ervaring krijgen in hun werk. In het bank en verzekeringswezen en de overige industrie maakt men daarentegen wel vaak gebruik van deze vorm van kennisverwerving. Nog geen kwart van de bedrijven leidt leerlingen of stagiaires op. In de sectoren handel en reparatie, bouw en onroerend goed en de metaal en elektrotechniek is het percentage bedrijven dat jongeren opleidt het hoogst. De voedingsindustrie is de sector waar de bedrijven de meeste aandacht besteden aan het opleiden van ongeschoolde arbeidskrachten.

Verder blijken de meeste vormen van kennisverwerving meer voor te komen bij grote bedrijven dan bij kleine bedrijven. Een uitzondering daarop vormt het in dienst nemen van ongeschoolden en deze vervolgens opleiden. Deze manier om nieuwe kennis in huis te halen komt iets meer voor bij de kleine bedrijven. 
Tabel 3.2

Belangrijkste manieren om nieuwe kennis en deskundigheid in huis te halen, 1997-1999

\begin{tabular}{|c|c|c|c|c|c|c|}
\hline \multirow[t]{2}{*}{ Bedrijfssector/bedrijfsgrootte } & \multicolumn{4}{|c|}{ ervaring training jongeren werklozen } & \multicolumn{2}{|c|}{$\begin{array}{l}\text { onge- gekwali- } \\
\text { schoolden ficeerden }\end{array}$} \\
\hline & $\%$ & $\%$ & $\%$ & $\%$ & & \\
\hline \multicolumn{7}{|l|}{ Bedrijfssector } \\
\hline $\begin{array}{l}\text { Voeding } \\
\text { Chemie } \\
\text { Metaal en elektrotechniek } \\
\text { Overige industrie } \\
\text { Energie } \\
\text { Bouw en onroerend goed } \\
\text { Handel en reparatie } \\
\text { Transport en communicatie } \\
\text { Bank en verzekeringswezen } \\
\text { Horeca en zakelijke dienstverlening } \\
\text { Kwartaire diensten }\end{array}$ & $\begin{array}{l}45 \\
46 \\
46 \\
54 \\
46 \\
39 \\
50 \\
28 \\
56 \\
54 \\
29\end{array}$ & $\begin{array}{l}78 \\
87 \\
87 \\
78 \\
95 \\
87 \\
89 \\
81 \\
89 \\
80 \\
86\end{array}$ & $\begin{array}{c}15 \\
13 \\
25 \\
20 \\
- \\
27 \\
28 \\
21 \\
13 \\
17 \\
-\end{array}$ & $\begin{array}{l}- \\
- \\
3 \\
7 \\
- \\
- \\
3 \\
- \\
8 \\
8 \\
-\end{array}$ & $\begin{array}{r}25 \\
12 \\
12 \\
- \\
15 \\
9 \\
8 \\
- \\
14\end{array}$ & $\begin{array}{l}57 \\
58 \\
54 \\
43 \\
63 \\
32 \\
50 \\
42 \\
58 \\
57 \\
68\end{array}$ \\
\hline \multicolumn{7}{|l|}{ Bedrijfsgrootte } \\
\hline $\begin{array}{l}10-19 \text { werknemers } \\
20-99 \text { werknemers } \\
100-499 \text { werknemers } \\
\text { meer dan } 500 \text { werknemers }\end{array}$ & $\begin{array}{l}39 \\
49 \\
58 \\
57\end{array}$ & $\begin{array}{l}78 \\
86 \\
91 \\
96\end{array}$ & $\begin{array}{l}20 \\
25 \\
23 \\
27\end{array}$ & $\begin{array}{l}6 \\
5 \\
5 \\
6\end{array}$ & $\begin{array}{l}13 \\
11 \\
12 \\
11\end{array}$ & $\begin{array}{l}44 \\
51 \\
56 \\
65\end{array}$ \\
\hline Totaal & 47 & 85 & 23 & 5 & 12 & 49 \\
\hline
\end{tabular}

Bron: CBS (Enquête bedrijfsopleidingen)/ ROA

- = niet beschikbaar

\subsection{HRD-instrumenten}

Bedrijven kunnen hun HRD-beleid op verschillende manieren vormgeven. In deze paragraaf wordt achtereenvolgens aandacht besteed aan een aantal verschillende HRD-instrumenten waarmee het HRD-beleid gestalte gegeven kan worden. Achtereenvolgens komen aan de orde: opleidingsplannen, opleidingsbudgetten, het hebben van een intern opleidingscentrum, faciliteiten voor opleidingen op de werkplek en collectieve (al dan niet CAO-) afspraken rond de opleidingsinspanningen van het personeel.

\section{Opleidingsplannen en budgetten}

Sommige bedrijven leggen hun opleidingsbeleid vast in een opleidingsplan, waarin wordt aangegeven wat ze aan de opleiding van hun personeel willen doen. Een andere manier om het opleiden van het personeel te faciliteren is het vastleggen van een opleidingsbudget, een bedrag dat gereserveerd wordt voor de kosten van het scholen van het personeel. In de eerste kolom van tabel 3.3 wordt het percentage bedrijven met een geschreven opleidingsplan weergegeven. In de tweede kolom wordt een overzicht gegeven van het percentage bedrijven dat een opleidingsbudget heeft. Hieruit blijkt dat bedrijven met een opleidingsplan ook vaak een opleidingsbudget hebben. Uit de tabel blijkt dat met name grote bedrijven vaak een opleidingsplan hebben. Opleidingsplannen komen het vaakst voor in de sectoren chemie en metaal en elektrotechniek. Wat verder opvalt is dat in de sector kwartaire diensten 
slechts één op de acht organisaties over een geschreven opleidingsplan beschikt, maar dat bijna de helft van de organisaties in die sector beschikt over een opleidingsbudget.

Tabel 3.3

Percentage bedrijven met een geschreven opleidingsplan en/of opleidingsbudget, 1999

\begin{tabular}{lcc}
\hline Bedrijfssector/bedrijfsgrootte & opleidingsplan & opleidingsbudget \\
\hline Bedrijfssector & $\%$ & $\%$ \\
Voeding & 22 & 18 \\
Chemie & 37 & 40 \\
Metaal en elektrotechniek & 30 & 25 \\
Overige industrie & 17 & 23 \\
Energie & 27 & 38 \\
Bouw en onroerend goed & 29 & 19 \\
Handel en reparatie & 20 & 21 \\
Transport en communicatie & 18 & 14 \\
Bank en verzekeringswezen & 27 & 40 \\
Horeca en zakelijke dienstverlening & 21 & 28 \\
Kwartaire diensten & 13 & 45 \\
& & \\
Bedrijfsgrootte & & \\
10-19 werknemers & 17 & 14 \\
20-99 werknemers & 23 & 24 \\
me-499 werknemers & 48 & 57 \\
meer dan 500 werknemers & 70 & 81 \\
Totaal & 23 & 23
\end{tabular}

Bron: CBS (Enquête bedrijfsopleidingen)/ ROA

Intern opleidingscentrum en opleidingsfaciliteiten

In tabel 3.4 wordt een beeld geschetst van de mate waarin bedrijven beschikken over een intern opleidingscentrum en faciliteiten hebben voor opleidingen op de werkplek. De tabel laat zien dat met name in de sectoren energie en in het bank- en verzekeringswezen bedrijven relatief vaak over een eigen opleidingscentrum beschikken. Daarnaast blijkt dat grotere bedrijven vaker over een eigen opleidingscentrum beschikken dan kleine bedrijven. Dit kan verklaard worden door schaalvoordelen die grote bedrijven kunnen hebben bij het opzetten van interne opleidingcentra.

Bedrijven hebben opleidingsfaciliteiten voor opleidingen op de werkplek wanneer ze beschikken over instrumenten, apparatuur, videofaciliteiten of een ruimte die gebruik wordt voor het opleiden van mensen op de werkplek. De tweede kolom van tabel 5.4 laat zien dat het percentage bedrijven dat over dergelijke faciliteiten beschikt veel groter is bij grote bedrijven dan bij kleinere. 
Tabel 3.4

Percentage bedrijven met intern opleidingscentrum en/of faciliteiten voor opleidingen op de werkplek, 1999

\begin{tabular}{lcc}
\hline Bedrijfssector/bedrijfsgrootte & $\begin{array}{c}\text { intern } \\
\text { opleidingscentrum }\end{array}$ & opleidingsfaciliteiten \\
\hline Bedrijfssector & $\%$ & $\%$ \\
Voeding & 4 & 21 \\
Chemie & 8 & 36 \\
Metaal en elektrotechniek & 8 & 27 \\
Overige industrie & 7 & 19 \\
Energie & 29 & 47 \\
Bouw en onroerend goed & 4 & 14 \\
Handel en reparatie & 11 & 27 \\
Transport en communicatie & 4 & 19 \\
Bank en verzekeringswezen & 15 & 41 \\
Horeca en zakelijke dienstverlening & 10 & 29 \\
Kwartaire diensten & 9 & 31 \\
Bedrijfsgrootte & & \\
10-19 werknemers & & 15 \\
20-99 werknemers & 4 & 26 \\
mo-499 werknemers & 8 & 54 \\
meer dan 500 werknemers & 23 & 74 \\
Totaal & 51 & 24 \\
\end{tabular}

Bron: CBS (Enquête bedrijfsopleidingen) / ROA

\section{Collectieve opleidingsafspraken en aandeel van CAO's}

In de eerste kolom van tabel 3.5 wordt een overzicht gegeven van het percentage bedrijven dat collectieve afspraken heeft gericht op de scholing van hun personeel. Uit de tabel blijkt dat afspraken over opleidingen relatief weinig voorkomen in de chemie. In de energiesector daarentegen heeft ruim de helft van de bedrijven een collectieve afspraak over de scholing van het personeel. Verder geldt dat grotere bedrijven vaker collectieve afspraken maken over opleidingen dan de kleinere bedrijven.

Uit de tweede kolom van tabel 3.5 blijkt dat over de gehele linie ongeveer de helft van de collectieve afspraken tot de CAO behoren. In de sectoren energie en bouw en onroerend goed is het aandeel van CAO-afspraken opvallend hoger: respectievelijk 74 en $77 \%$ van de collectieve opleidingsafspraken behoren tot de CAO. ${ }^{5}$ In de handel en reparatie en het bank en verzekeringswezen is het aandeel van de in de CAO vastgelegde opleidingsafspraken beduidend lager (36\%). Overigens blijkt uit een analyse van een aantal CAO's door het NEI dat 93\% van de onderzochte CAO's afspraken over scholing bevatten. Opmerkelijk is ook dat bij de grotere bedrijven meer afspraken over opleidingen zijn vastgelegd in de CAO dan bij de kleinere en middelgrote bedrijven.

5. Het hoge cijfer voor de sector bouw en onroerend goed wordt overigens bevestigd door het $\mathrm{NEI}$ in een analyse van $\mathrm{CAO}$ afspraken. 
Tabel 3.5

Percentage bedrijven met collectieve afspraken over opleidingen, 1999

\begin{tabular}{lcc}
\hline Bedrijfssector/bedrijfsgrootte & collectieve afspraken & $\begin{array}{c}\text { aandeel van CAO-afspraken } \\
\text { in collectieve afspraken }\end{array}$ \\
\hline Bedrijfssector & $\%$ & $\%$ \\
Voeding & 22 & 50 \\
Chemie & 21 & 46 \\
Metaal en elektrotechniek & 33 & 55 \\
Overige industrie & 20 & 51 \\
Energie & 51 & 74 \\
Bouw en onroerend goed & 37 & 77 \\
Handel en reparatie & 27 & 56 \\
Transport en communicatie & 26 & 36 \\
Bank en verzekeringswezen & 33 & 38 \\
Horeca en zakelijke dienstverlening & 36 & 48 \\
Kwartaire diensten & 27 & \\
Bedrijfsgrootte & & 47 \\
10-19 werknemers & & 49 \\
$20-99$ werknemers & 26 & 69 \\
me-499 werknemers & 32 & 50 \\
meer dan 500 werknemers & 45 & \\
Totaal & 68 & \\
\hline
\end{tabular}

Bron: CBS (Enquête bedrijfsopleidingen)/ ROA

\subsection{Gebruikte opleidings- en ontwikkelingsinstrumenten}

In tabel 3.6 wordt een overzicht gegeven van de mate waarin bedrijven gebruik maken van bepaalde opleidings- en ontwikkelingsinstrumenten in hun HRD-beleid. Externe opleidingen zijn het meest gebruikte opleidings- en ontwikkelingsinstrument. Maar liefst $78 \%$ van de bedrijven geeft aan haar personeel extern op te leiden. Interne opleidingen worden daarentegen slechts in een kwart van alle bedrijven gebruikt, waarbij het vooral de grote bedrijven zijn die vaak intern opleiden. In deze grote bedrijven vervullen deze interne opleidingen ook een belangrijke rol in hun interne arbeidsmarkt (Dekker, De Grip \& Heijke, 2002). De minst gebruikte opleidings- en ontwikkelingsinstrumenten zijn functieroulatie en zogenaamde kwaliteitscirkels. Kleinere bedrijven hebben weinig mogelijkheden om deze instrumenten te hanteren.

Wanneer gekeken wordt naar verschillen tussen bedrijfssectoren blijkt dat in de sector voeding relatief weinig externe opleidingen worden gevolgd, terwijl in deze sector functieroulatie juist opvallend vaak als HRD instrument wordt ingezet. De sector chemie scoort hoog wat betreft interne opleidingen, werkplek opleidingen en zelfstudie. De sectoren bouw en onroerend goed en transport en communicatie scoren voor het merendeel van de genoemde HRD-instrumenten relatief laag; wel worden er in de bouw veel externe opleidingen gevolgd. 
Tabel 3.6

Percentage bedrijven dat verschillende opleidings- en ontwikkelingsinstrumenten toepast, 1999

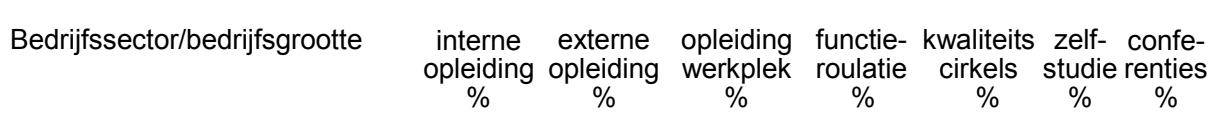

\begin{tabular}{|c|c|c|c|c|c|c|c|}
\hline \multicolumn{8}{|l|}{ Bedrijfssector } \\
\hline $\begin{array}{l}\text { Voeding } \\
\text { Chemie } \\
\text { Metaal en elektrotechniek } \\
\text { Overige industrie } \\
\text { Energie } \\
\text { Bouw en onroerend goed } \\
\text { Handel en reparatie } \\
\text { Transport en communicatie } \\
\text { Bank en verzekeringswezen } \\
\text { Horeca/zakelijke dienstverlening } \\
\text { Kwartaire diensten }\end{array}$ & $\begin{array}{l}23 \\
40 \\
29 \\
26 \\
47 \\
14 \\
29 \\
19 \\
36 \\
30 \\
22\end{array}$ & $\begin{array}{l}63 \\
85 \\
85 \\
73 \\
87 \\
85 \\
76 \\
68 \\
88 \\
79 \\
71\end{array}$ & $\begin{array}{l}52 \\
59 \\
56 \\
54 \\
51 \\
32 \\
54 \\
33 \\
56 \\
54 \\
41\end{array}$ & $\begin{array}{r}28 \\
17 \\
19 \\
23 \\
17 \\
3 \\
13 \\
9 \\
20 \\
15 \\
10\end{array}$ & $\begin{array}{r}18 \\
16 \\
16 \\
11 \\
22 \\
12 \\
14 \\
9 \\
17 \\
19 \\
19\end{array}$ & $\begin{array}{l}20 \\
46 \\
28 \\
24 \\
44 \\
15 \\
37 \\
18 \\
56 \\
38 \\
30\end{array}$ & $\begin{array}{l}42 \\
58 \\
51 \\
48 \\
65 \\
40 \\
49 \\
32 \\
72 \\
58 \\
57\end{array}$ \\
\hline \multicolumn{8}{|l|}{ Bedrijfsgrootte } \\
\hline $\begin{array}{l}10-19 \text { werknemers } \\
20-99 \text { werknemers } \\
100-499 \text { werknemers } \\
\text { meer dan } 500 \text { werknemers }\end{array}$ & $\begin{array}{l}18 \\
26 \\
52 \\
82\end{array}$ & $\begin{array}{l}71 \\
82 \\
93 \\
97\end{array}$ & $\begin{array}{l}39 \\
53 \\
71 \\
84\end{array}$ & $\begin{array}{r}9 \\
13 \\
29 \\
45\end{array}$ & $\begin{array}{l}12 \\
15 \\
23 \\
37\end{array}$ & $\begin{array}{l}21 \\
33 \\
53 \\
67\end{array}$ & $\begin{array}{l}38 \\
53 \\
77 \\
88\end{array}$ \\
\hline Totaal & 25 & 78 & 49 & 13 & 15 & 30 & 49 \\
\hline
\end{tabular}

Bron: CBS (Enquête bedrijfsopleidingen)/ ROA

\subsection{Soorten opleidingen}

Gegevens van het NEI op basis van een analyse van CAO afspraken laten zien dat de meeste scholing (42\%) functiegericht is. Toch verschilt de inhoud van de gevolgde opleidingen tussen de diverse bedrijfssectoren. In tabel 3.7 wordt een overzicht gegeven van de aard van de in- en externe opleidingen in de verschillende bedrijfssectoren en bedrijfsgrootten. Hierbij gaat het telkens om het percentage bedrijven waar een bepaald soort cursus wordt gevolgd.

De verschillen tussen bedrijfssectoren en bedrijven van verschillende omvang kunnen zowel ontstaan door aanbod- als vraagfactoren. Zo kan er in een bepaalde bedrijfssector veel nadruk liggen op het gebruik van specialistische competenties, die door functiespecifieke opleidingen van het personeel op peil gehouden moeten worden, terwijl andere sectoren juist meer steunen op algemene vaardigheden, wat zich vertaalt in een hoge deelname aan algemeen vormende opleidingen. Aan de andere kant kunnen de verschillen ook samenhangen met de samenstelling van het personeel in de verschillende bedrijfssectoren. Wanneer bepaalde bedrijfssectoren recruteren uit specifieke segmenten van de arbeidsmarkt, kan het scholingspatroon van het personeel in dienst verschillen doordat deze werknemers uit deze specifieke segmenten bepaalde competentietekorten hebben. 
Tabel 3.7

Percentage bedrijven waarin interne (in) of externe (ex) opleidingen worden gevolgd, 1999

\begin{tabular}{|c|c|c|c|c|c|c|c|c|c|c|c|c|c|c|c|c|c|c|c|c|}
\hline Bedrijfssector/bedrijfsgrootte & \multicolumn{2}{|c|}{ talen } & \multicolumn{2}{|c|}{$\begin{array}{l}\text { verkoop en } \\
\text { marketing }\end{array}$} & \multicolumn{2}{|c|}{$\begin{array}{l}\text { boekhouding/ } \\
\text { financiën }\end{array}$} & \multicolumn{2}{|c|}{ Management } & \multicolumn{2}{|c|}{ kantoorwerk } & \multicolumn{2}{|c|}{$\begin{array}{c}\text { persoonlijke } \\
\text { vaardigheden }\end{array}$} & \multicolumn{2}{|c|}{ informatica } & \multicolumn{2}{|c|}{ techniek } & \multicolumn{2}{|c|}{ milieu/arbo } & \multicolumn{2}{|c|}{ diensten } \\
\hline \multicolumn{21}{|l|}{ Bedrijfssector } \\
\hline $\begin{array}{l}\text { Voeding } \\
\text { Chemie } \\
\text { Metaal en elektrotechniek } \\
\text { Overige industrie } \\
\text { Energie } \\
\text { Bouw en onroerend goed } \\
\text { Handel en reparatie } \\
\text { Transport en communicatie } \\
\text { Bank en verzekeringswezen } \\
\text { Horeca/zakelijke dienstverl. } \\
\text { Kwartaire diensten }\end{array}$ & $\begin{array}{l}- \\
6 \\
1 \\
2 \\
- \\
- \\
2 \\
2 \\
4 \\
2 \\
-\end{array}$ & $\begin{array}{r}12 \\
32 \\
15 \\
11 \\
25 \\
1 \\
10 \\
9 \\
17 \\
8 \\
18\end{array}$ & $\begin{array}{r}- \\
- \\
2 \\
3 \\
- \\
- \\
10 \\
3 \\
13 \\
6 \\
-\end{array}$ & $\begin{array}{r}18 \\
22 \\
16 \\
16 \\
24 \\
13 \\
31 \\
5 \\
30 \\
16 \\
19\end{array}$ & $\begin{array}{r}- \\
- \\
2 \\
- \\
- \\
- \\
1 \\
2 \\
18 \\
5 \\
-\end{array}$ & $\begin{array}{l}11 \\
32 \\
16 \\
18 \\
36 \\
16 \\
18 \\
13 \\
66 \\
24 \\
17\end{array}$ & $\begin{array}{l}4 \\
7 \\
2 \\
4 \\
- \\
2 \\
3 \\
3 \\
4 \\
7 \\
-\end{array}$ & $\begin{array}{l}20 \\
37 \\
33 \\
25 \\
50 \\
16 \\
23 \\
13 \\
32 \\
30 \\
40\end{array}$ & $\begin{array}{l}- \\
- \\
- \\
- \\
- \\
- \\
1 \\
2 \\
6 \\
2 \\
-\end{array}$ & $\begin{array}{r}3 \\
8 \\
6 \\
5 \\
18 \\
6 \\
7 \\
4 \\
15 \\
8 \\
13\end{array}$ & $\begin{array}{r}9 \\
14 \\
5 \\
6 \\
- \\
2 \\
8 \\
7 \\
18 \\
11 \\
7\end{array}$ & $\begin{array}{l}19 \\
23 \\
15 \\
19 \\
46 \\
18 \\
21 \\
14 \\
26 \\
27 \\
40\end{array}$ & $\begin{array}{r}5 \\
16 \\
9 \\
10 \\
31 \\
3 \\
10 \\
8 \\
16 \\
11 \\
9\end{array}$ & $\begin{array}{l}23 \\
52 \\
43 \\
40 \\
56 \\
23 \\
32 \\
21 \\
46 \\
37 \\
44\end{array}$ & $\begin{array}{r}9 \\
24 \\
17 \\
10 \\
24 \\
4 \\
10 \\
2 \\
- \\
3 \\
-\end{array}$ & $\begin{array}{r}31 \\
54 \\
59 \\
34 \\
54 \\
58 \\
33 \\
14 \\
6 \\
13 \\
17\end{array}$ & $\begin{array}{r}8 \\
15 \\
5 \\
5 \\
20 \\
10 \\
3 \\
4 \\
- \\
6 \\
-\end{array}$ & $\begin{array}{r}33 \\
53 \\
53 \\
37 \\
58 \\
58 \\
31 \\
33 \\
16 \\
31 \\
-\end{array}$ & $\begin{array}{r}- \\
10 \\
2 \\
3 \\
- \\
- \\
2 \\
5 \\
- \\
3 \\
-\end{array}$ & $\begin{array}{r}15 \\
32 \\
20 \\
17 \\
26 \\
14 \\
14 \\
33 \\
7 \\
20 \\
3\end{array}$ \\
\hline \multicolumn{21}{|l|}{ Bedrijfsgrootte } \\
\hline Totaal & 2 & 9 & 5 & 19 & 2 & 20 & 4 & 25 & 1 & 1 & 8 & 21 & 9 & 33 & 8 & 33 & 6 & 38 & 2 & 17 \\
\hline
\end{tabular}

Bron: CBS (Enquête bedrijfsopleidingen)/ ROA

$-=$ niet beschikbaar 
In figuur 3.1 wordt het percentage werknemers per bedrijf dat een interne cursus volgde in 1999 per type cursus en bedrijfssector afgebeeld.

Figuur 3.1

Percentage werknemers per bedrijfssector met interne opleidingen, naar soort opleiding, 1999

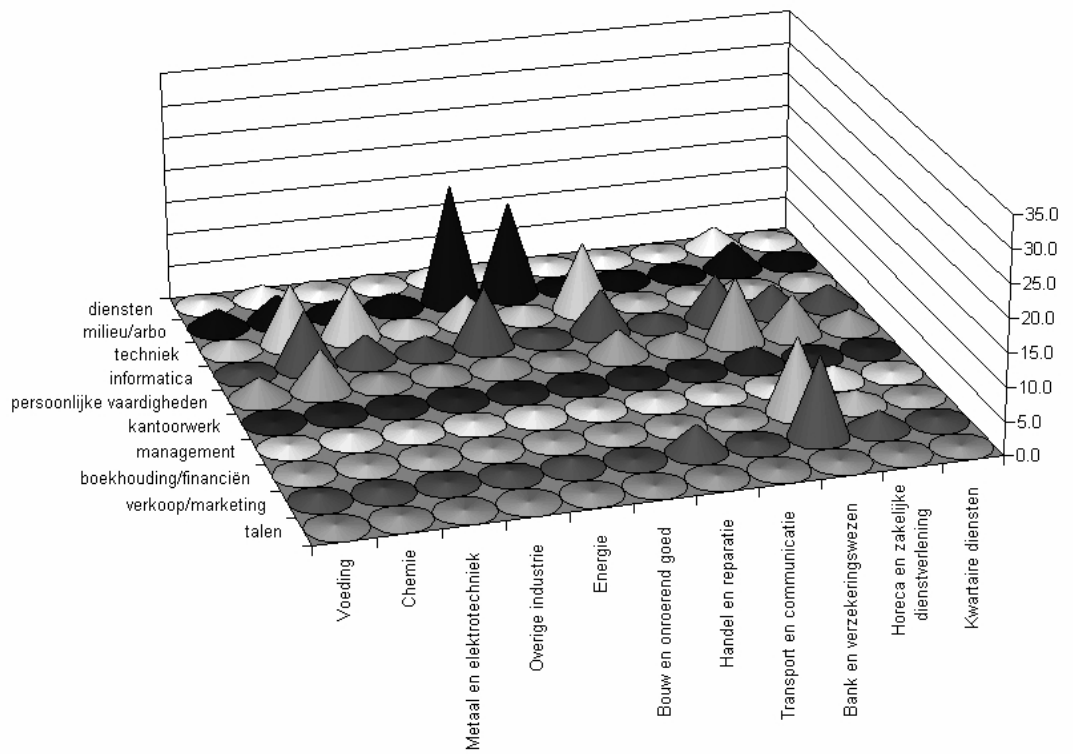

Interne cursussen op het gebied van milieu en arbeidsomstandigheden worden door een relatief groot deel van het personeel in de sectoren energie $(18,1 \%)$ en bouw en onroerend goed $(14,5 \%)$ gevolgd. Interne technische cursussen worden met name gevolgd door veel werkenden in de chemie, de metaal en elektrotechniek en in de sector handel en reparatie $(9,3 \%, 8,1 \%$ en $10,5 \%)$. Interne informaticacursussen worden met name door het personeel van bedrijven in de sectoren chemie $(9,3 \%)$ en energie $(9,0 \%)$ gevolgd. Met deelnamepercentages van $9,8 \%, 11,4 \%$ en $12,1 \%$ komen interne cursussen persoonlijke vaardigheden, boekhouden en verkoop en marketing relatief veel voor in het bank- en verzekeringswezen.

In figuur 3.2 wordt het percentage werknemers dat in 1999 een externe cursus volgde per bedrijfssector afgebeeld. Hieruit blijkt dat werknemers in de sectoren energie en bouw en onroerend goed relatief veel externe cursussen op het gebied van milieu en arbeidsomstandigheden volgen. Externe technische cursussen worden relatief vaak door werknemers in de sector bouw en onroerend goed gevolgd $(22,4 \%)$. De deelname aan externe informaticacursussen en externe cursussen op het gebied van boekhouding en financiën is relatief hoog in het bank- en verzekeringswezen $(21,8 \%$ en $20,3 \%)$. 
Figuur 3.2

Percentage werknemers per bedrijfssector met externe opleidingen, naar soort opleiding, 1999

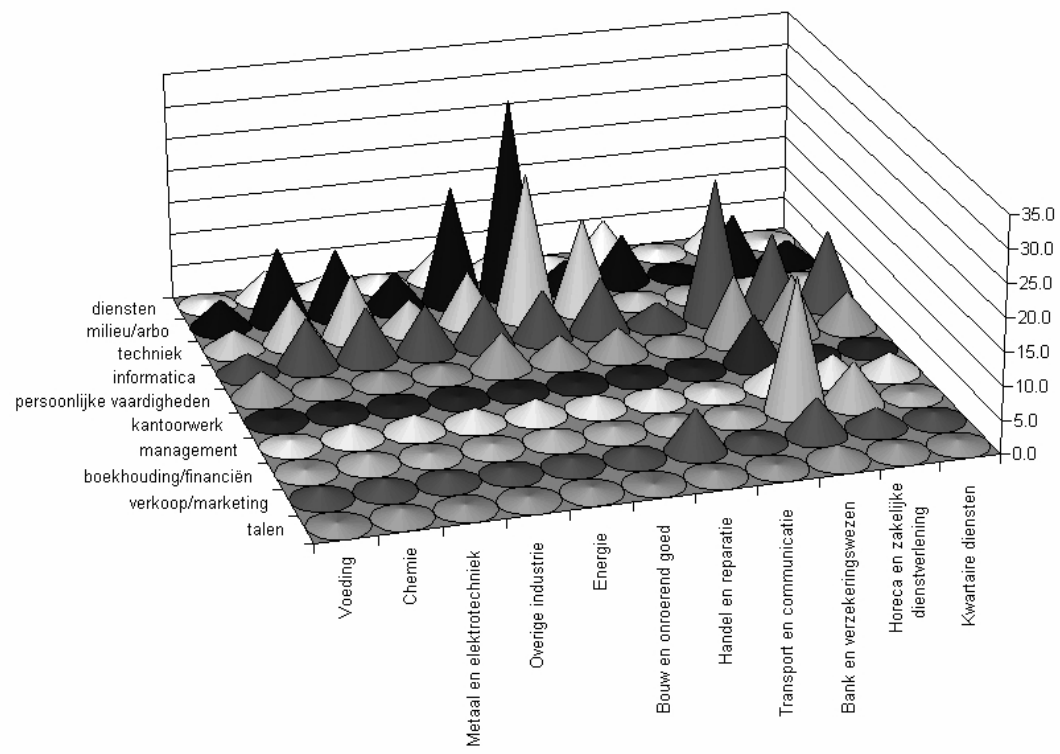

\subsection{Kosten van bedrijfsopleidingen}

Tabel 3.8 geeft een overzicht van de kosten die gemoeid zijn met bedrijfsopleidingen. Het gaat hier zowel om directe kosten zoals cursusgelden als indirecte kosten vanwege een verlies van productieve arbeidstijd. De gemiddelde kosten per werknemer vormen een indicator voor de mate waarin er geïnvesteerd wordt in de competenties van het totale personeelsbestand. De tweede indicator zegt iets over de gemiddelde kosten per getrainde werknemer.

De opleidingskosten per werknemer zijn het laagste in de sectoren voeding, transport en communicatie en kwartaire diensten. In de sectoren energie en bank- en verzekeringswezen zijn de opleidingskosten per werknemer daarentegen het hoogst. In deze bedrijfssectoren zijn ook de opleidingskosten per getrainde werknemer het hoogst. Grote bedrijven blijken niet alleen meer werknemers te scholen, maar ook meer uit te geven aan iedere opgeleide werknemer. Dit wijst op een hogere intensiteit of kwaliteit van de door de werknemers in de grotere bedrijven gevolgde opleidingen.

\subsection{Enkele trends}

Ook het HRD-beleid zelf is onderhevig aan veranderingen. De hogere kwaliteitseisen die aan organisaties gesteld worden en de krapte op de arbeidsmarkt worden veelal genoemd als de belangrijkste redenen daarvoor (Willemsen et al., 2000). Om te kijken welke trends binnen de verschillende bedrijfssectoren en -groottes plaatsvinden, wordt in figuur 3.3 een overzicht gegeven van de tussen 1993 en 1999 opgetreden veranderingen van het percentage bedrijven dat specifieke opleidingsen ontwikkelingsinstrumenten gebruikt. 
Tabel 3.8

Gemiddelde kosten van opleidingen, 1999

\begin{tabular}{lrc}
\hline Bedrijfssector/bedrijfsgrootte & Per werknemer & Per getrainde werknemer \\
\hline Bedrijfssector & $€$ & $€$ \\
Voeding & 840 & 2.569 \\
Chemie & 1.472 & 3.423 \\
Metaal en elektrotechniek & 1.212 & 3.353 \\
Overige industrie & 1.013 & 3.401 \\
Energie & 2.382 & 4.406 \\
Bouw en onroerend goed & 1.380 & 2.531 \\
Handel en reparatie & 1.380 & 3.202 \\
Transport en communicatie & 670 & 2.410 \\
Bank en verzekeringswezen & 2.479 & 4.147 \\
Horeca en zakelijke dienstverlening & 2.045 & 3.941 \\
Kwartaire diensten & 988 & 3.756 \\
Bedrijfsgrootte & & \\
& & \\
10-19 werknemers & 1.471 & 2.915 \\
10-99-499 werknemers & 1.358 & 3.279 \\
meer dan 500 werknemers & 2.618 & 3.926 \\
& 2.080 & 4.538 \\
\hline
\end{tabular}

Bron: CBS (Enquête bedrijfsopleidingen)/ ROA

De figuur laat zien dat over de gehele linie het systematisch vaststellen van de competentiebehoeften van de organisatie en het hebben van opleidingsplannen en budgetten tussen 1993 en 1999 is afgenomen, terwijl het vaststellen van de ontwikkelingsbehoeften van werknemers en het hebben van een opleidingscentrum juist toeneemt. Het vaststellen van de ontwikkelingsbehoeften van individuele werknemers is in alle sectoren toegenomen. Daarmee lijkt zich een individualisering van het opleidingsbeleid van bedrijven af te tekenen. Er zijn echter ook verschillen in de trends in het gebruik van bepaalde instrumenten. Zo is er bijvoorbeeld in de sectoren bank- en verzekeringswezen en kwartaire diensten een toenemend aantal bedrijven dat de competentiebehoeften van de organisatie systematisch vaststelt, terwijl in de sectoren transport en communicatie, voeding en bouw en onroerend goed minder bedrijven hun opleidingsbehoeften systematisch vaststellen. Ook is er, in tegenstel ling tot het algemene beeld, een positieve trend zichtbaar in het gebruik van opleidingsbudgetten in het bank- en verzekeringswezen, en in de kwartaire diensten. Daarnaast is er een aantal bedrijfssectoren waar het gebruik van opleidingsplannen toeneemt in tegenstelling tot de algemene daling van het gebruik van dit instrument. Ten slotte valt op dat bij drie bedrijfssectoren - voeding, chemie en transport en communicatie - sprake is van een daling van het percentage bedrijven dat de beschikking heeft over een eigen opleidingscentrum. 
Figuur 3.3

Veranderingen in het gebruik van HRM instrumenten tussen 1993 en 1999, per bedrijfssector en bedrijfsgrootte

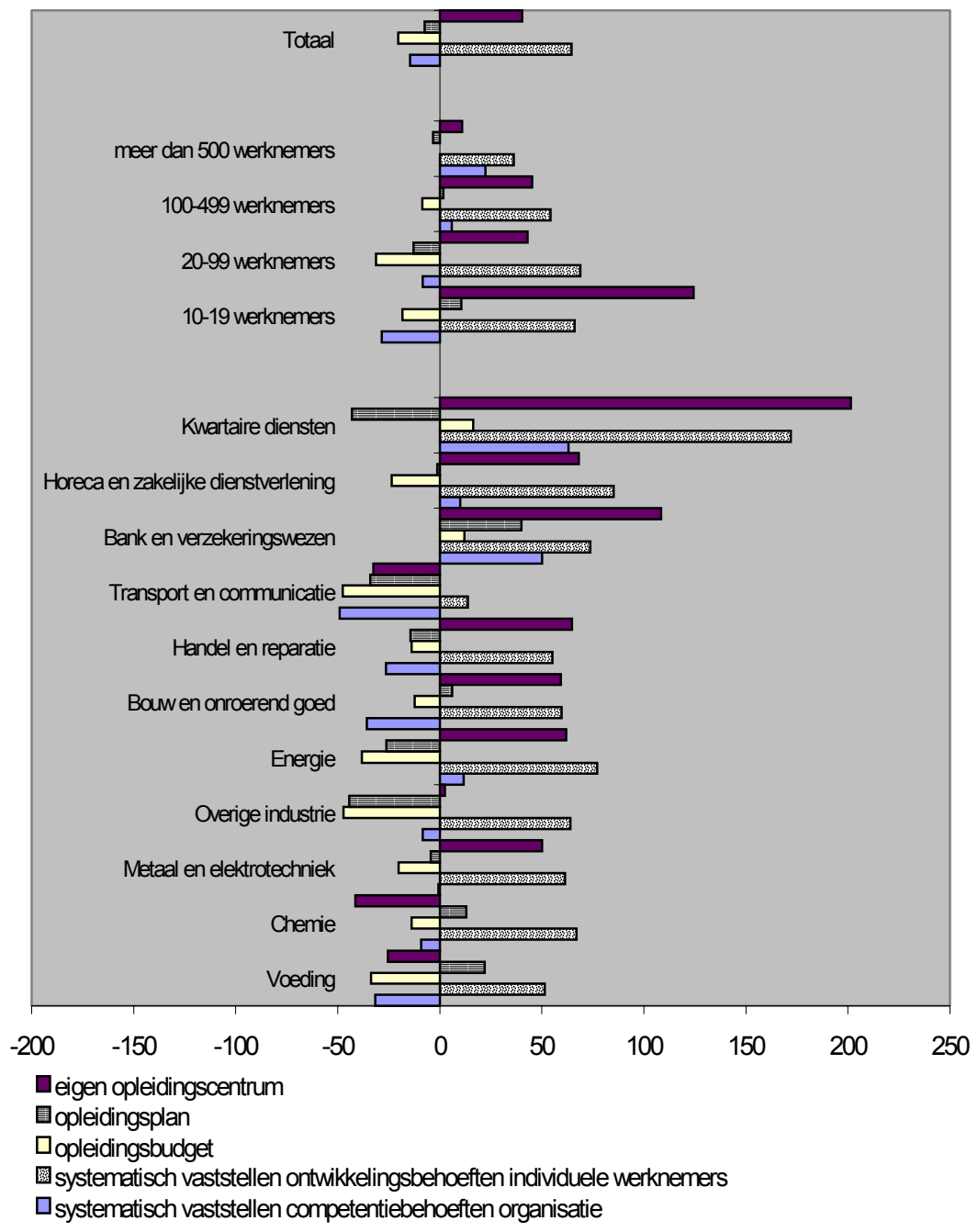

\subsection{Conclusies}

In dit hoofdstuk is er een overzicht gegeven van het HRD-beleid en de opleidingsinspanningen van het Nederlandse bedrijfsleven. Wanneer er gekeken wordt naar het huidige HRD-beleid blijkt dat de helft van de Nederlandse bedrijven aangeeft dat ze genoodzaakt zijn om nieuwe deskundigheid in huis te halen. In deze behoefte wordt het meest voorzien door het opleiden van het personeel dat al in dienst is. Ter ondersteuning van het opleiden van de medewerkers heeft bijna een kwart van de bedrijven een opleidingsplan of -budget, maar er bestaan op dit punt grote verschillen tussen bedrijfssectoren en bedrijven van verschillende grootten grote verschillen. Dit geldt ook voor het gebruik van eigen, interne opleidingscentra: 
de helft van de grootste bedrijven heeft de beschikking over een intern opleidingscentrum tegenover slechts $4 \%$ van de kleinere bedrijven.

Het meest gebruikte instrument om het personeel te ontwikkelen is het aanbieden van externe opleidingen. De meeste externe opleidingen die het bedriffsleven aanbiedt zijn cursussen op het gebied van informatica, techniek en bouw en milieu en arbeidsomstandigheden. De totale uitgaven voor de ontwikkeling van het personeel verschillen sterk tussen de verschillende bedrijfssectoren. Zo wordt er bijvoorbeeld in het bank- en verzekeringswezen per medewerker bijna vier maal zo veel gespendeerd aan aanvullende opleidingen en trainingen dan in de sector transport en communicatie.

Om enkele trends te kunnen signaleren is tenslotte ook het HRD-beleid in 1993 vergeleken met dat van 1999. Deze vergelijking laat zien dat in het algemeen het systematisch vaststellen van de opleidingsbehoeften van de organisatie en het hebben van opleidingsplannen en -budgetten afneemt, terwijl het vaststellen van de ontwikkelingsbehoeften van werknemers en het hebben van een opleidingscentrum juist toeneemt. Toch zijn er tussen de verschillende bedrijfssectoren en -grootten ook duidelijke verschillen in de trends in het gebruik van de verschillende HRDinstrumenten te constateren. 


\section{De relatie tussen het HRD-beleid en de bedrijfsprestaties: de empirie}

\subsection{Inleiding}

In dit hoofdstuk wordt er gekeken naar de opbrengsten van HRD-beleid. Er wordt in twee stappen gekeken in welke mate het investeren in de competenties van het personeel loont. Uitgaand van het theoretisch kader dat aan de orde kwam in hoofdstuk 2 wordt er allereerst gekeken naar de relatie tussen het HRD-beleid en de opleidingsinspanningen. In aansluiting daarop wordt er gekeken in hoeverre opleidingsinspanningen de bedrijfsprestaties beïnvloeden.

Het hoofdstuk is als volgt opgebouwd. In paragraaf 4.2 komt de relatie tussen diverse HRD-instrumenten en de opleidingsinspanningen aan de orde. In de daaropvolgende paragraaf (4.3) wordt er gekeken naar de mate waarin deze opleidingsinspanningen zich vertalen in bedrijfsresultaten. Daarbij zal ook ingegaan worden op de vraag in hoeverre de omgekeerde relatie ook opgaat. In paragraaf 4.4 wordt gekeken naar de korte-termijn effecten van verschillende soorten bedrijfsopleidingen. Paragraaf 4.5 sluit het hoofdstuk af met enkele conclusies.

\subsection{HRD-beleid en opleidingsinspanningen}

In deze paragraaf wordt gekeken in hoeverre het HRD-beleid een invloed heeft op de opleidingsparticipatie van het personeel van het bedrijf. Het HRM-beleid wordt daarbij in kaart gebracht door te kijken naar het gebruik van bepaalde HRD instrumenten. Daarnaast wordt er een onderscheid gemaakt tussen de deelname aan interne en externe opleidingen.

Bij bepaalde HRD-instrumenten kan op intuïtieve basis een positieve relatie met de opleidingsdeelname verwacht worden. Zo is het waarschijnlijk dat het hebben van een opleidingsbudget of een opleidingsplan een positief effect zal hebben op de scholingsparticipatie. Bij het vaststellen van de opleidingsbehoefte voor de organisatie en voor individuele werknemers zijn de verwachte effecten echter niet eenduidig op voorhand aan te geven. Het kan bijvoorbeeld zijn dat als een bedrijf haar opleidingsbehoefte grondig in kaart brengt, dit een remmend effect heeft op cursusdeelname, omdat de deelname aan bepaalde niet-noodzakelijk cursussen hierdoor verminderd wordt. Aan de andere kant kan het in kaart brengen van de opleidingsbehoefte ook HRD lacunes in de competenties van het personeel beter traceren, wat dan vervolgens de opleidingsdeelname juist stimuleert.

In figuur 4.1 wordt een schematisch overzicht gegeven van de relatie tussen het gebruik van HRD-instrumenten en de deelname van werknemers aan interne opleidingen. ${ }^{6}$ Het gemiddeld aantal interne bedrijfsopleidingen per medewerker wordt hier gehanteerd als indicator voor de interne opleidingsinspanningen. Daarmee blijft

6. De volledige schattingsresultaten zijn te vinden in tabel A.1 van de appendix. 
de duur en de kwaliteit van de opleidingen buiten beschouwing, wat een beperking van het onderzoek inhoudt. ${ }^{7}$ De geschetste relaties zijn allemaal statistisch significant en kunnen geïnterpreteerd worden als de toename van het gemiddeld aantal opleidingen per medewerker als gevolg van het gebruik van het betreffende HRDinstrument. ${ }^{8}$

Figuur 4.1

De invloed van diverse HRD-instrumenten op de deelname aan interne bedrijfsopleidingen

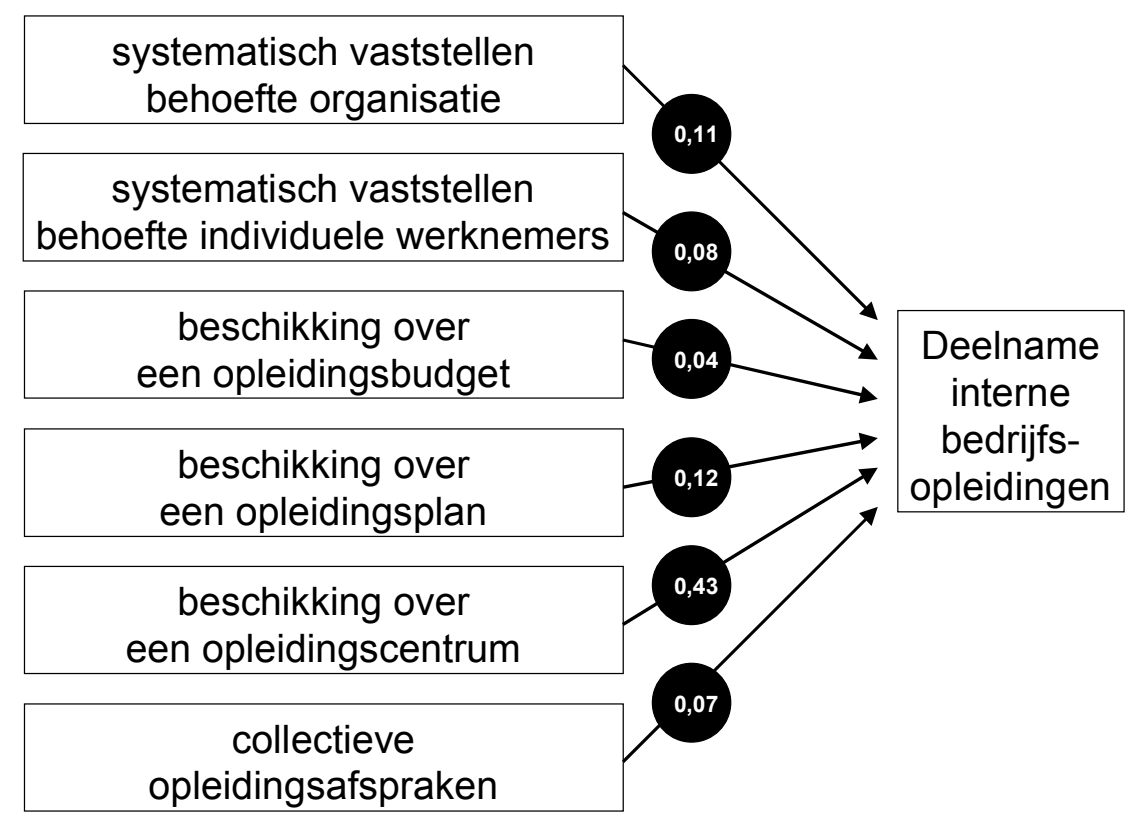

De figuur laat zien dat vijf van de zes in de analyse opgenomen HRD-instrumenten een relatief klein effect hebben op de deelname aan interne bedrijfsopleidingen. Zo leidt het systematisch vaststellen van de opleidingsbehoefte van de organisatie er toe dat alle medewerkers gemiddeld ongeveer een-tiende interne bedrijfscursus extra volgen. Zoals gezegd, is dit cijfer een onderschatting van het belang van dit instrument voor het bedrijf, omdat deze toename het saldo is van de additioneel gevolgde opleidingen waaraan behoefte bestaat en het minder volgen van opleidingen die geen bijdrage leveren aan het verminderen van de competentietekorten van het personeel. Het hebben van een intern opleidingscentrum heeft de grootste invloed op de participatie aan bedrijfsopleidingen. In bedrijven met een eigen opleidingscentrum wordt gemiddeld bijna een halve cursus per medewerker meer gevolgd dan in bedrijven die hier geen beschikking over hebben. Een mogelijke

7. Hoofdstuk 3 geeft wel een overzicht van de soorten cursussen die door het personeel van bedrijven gevolgd worden.

8. In de analyses is in eerste instantie ook aandacht besteed aan mogelijke synergie-effecten van verschillende HRD-instrumenten, maar de resultaten veranderen niet wezenlijk wanneer interactievariabelen, die deze synergie-effecten zouden moeten opvangen, in de schattingen worden opgenomen. 
interpretatie van deze bevinding is dat bedrijven die al een opleidingscentrum hebben de kosten die al gemaakt zijn proberen terug te verdienen.

In figuur 4.2 wordt een soortgelijke analyse uitgevoerd voor het gemiddeld aantal externe bedrijfsopleidingen per medewerker. ${ }^{9}$ Uit de figuur komt naar voren dat twee van de opgenomen HRD-instrumenten geen significant effect (NS) op de deelname aan externe cursussen hebben. Het betreft hier het systematisch vaststellen van de behoefte van de organisatie en de beschikking over een opleidingscentrum. De andere opleidingsinstrumenten hebben wel een significant effect, waarbij het hebben van een opleidingsbudget en de aanwezigheid van collectieve opleidingsafspraken de meeste invloed hebben op de deelname aan externe bedrijfsopleidingen.

Figuur 4.2

De invloed van diverse HRD-instrumenten op de deelname aan externe bedrijfsopleidingen

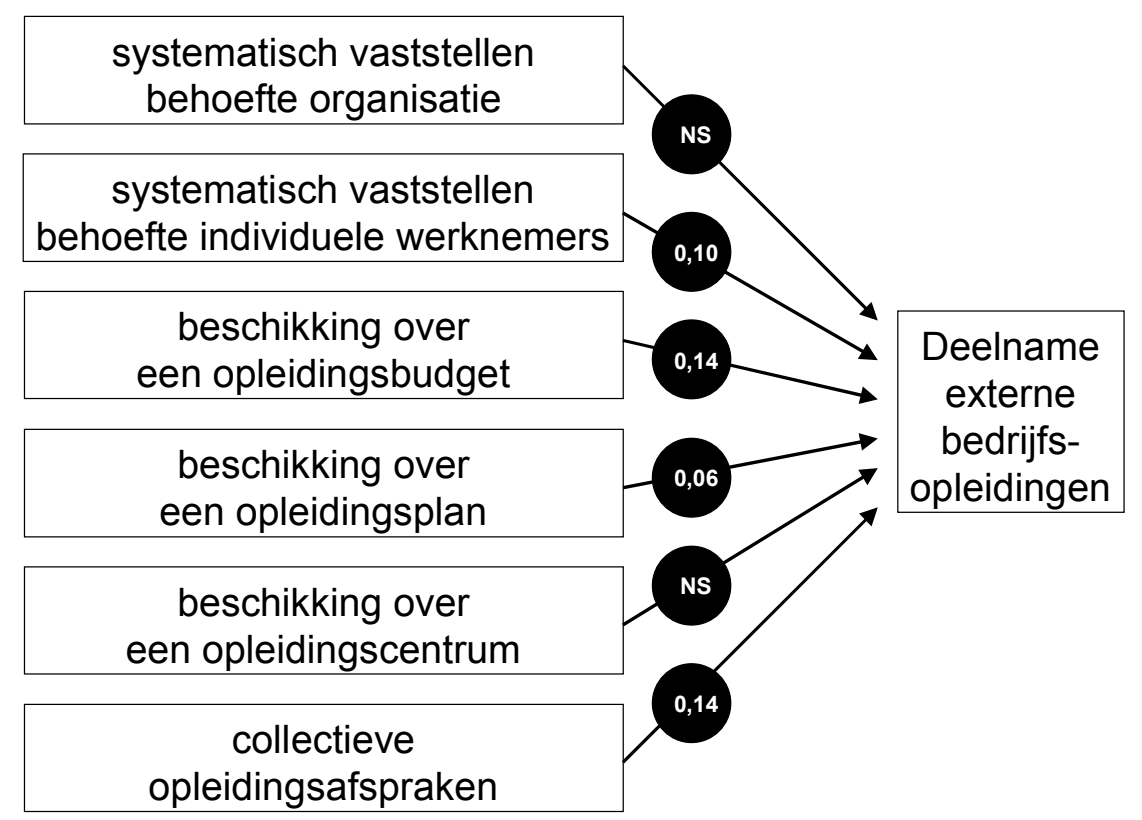

Wanneer de analyses met elkaar vergeleken worden blijkt allereerst dat de verklarende waarde van de eerste analyse met een $R^{2}$ van ruim 0.12 veel hoger is dan de verklarende waarde van de tweede analyse (0.062). Dit houdt in dat de relatie tussen opleidingsinstrumenten en opleidingsdeelname sterker is bij externe dan bij interne bedrijfsopleidingen. Daarnaast blijkt dat het opleidingsbudget belangrijker is voor externe opleidingen dan voor interne. Een opleidingsplan daarentegen heeft een groter effect op het aantal gevolgde interne opleidingen dan op de gevolgde externe opleidingen. Ten slotte hebben collectieve opleidingsafspraken een groter effect op de deelname aan externe opleidingen dan op de deelname aan interne bedrijfsopleidingen.

9. Tabel A.2 van de appendix bevat de volledige empirische resultaten. 
Daarnaast valt op dat enkele HRD-instrumenten een groter effect hebben op de deelname aan externe opleidingen als op de deelname aan interne opleidingen. Dit zou veroorzaakt kunnen worden door het feit dat externe opleidingen meestal duurder zijn en daarom een meer uitgebreide overweging van bedrijven vragen. Een ander verrassend effect is dat het hebben van een intern opleidingscentrum geen statistisch significant effect heeft op de deelname aan externe opleidingen. Het hebben van een intern opleidingscentrum heeft dus geen remmend effect op de deelname aan externe opleidingen.

De twee analyses laten zien dat bepaalde HRD-instrumenten de deelname aan zowel in- als externe opleidingsinspanningen positief beïnvloeden. Daarmee is aangetoond dat het HRD-beleid loont op het vlak van de participatie in bedrijfsopleidingen. In het volgende komt de tweede stap van het onderzoeksmodel aan de orde: de relatie tussen de opleidingsinspanningen en de bedrijfsprestaties.

\subsection{De relatie tussen opleidingsinspanningen en bedrijfsprestaties}

In deze paragraaf wordt voor een panel van Nederlandse bedrijven de relatie tussen opleiden en de bedrijfsprestaties onderzocht. Daarbij wordt er gekeken naar de in hoofdstuk 2 onderscheiden prestatiemaatstaven: De gemiddelde winst per medewerker, de 'return on sales' (ROS) en de gemiddelde productiviteit (gemeten door de gemiddelde verkopen per medewerker.

\section{Belang en opzet van de analyses}

Het belang van nieuw Nederlands onderzoek met betrekking tot de effectiviteit van opleidingsinspanningen ligt vooral in het verkrijgen van 'hardere' informatie over de mate waarin het investeren in het personeel voor bedrijven loont. Hoewel een adequaat opleidingsbeleid vanzelfsprekend ook op individuele werknemers positieve effecten kan hebben en verwacht mag worden dat deze individuele effecten vervolgens ook hun doorslag kunnen hebben op de organisatie als geheel, lijkt het goed om de aandacht expliciet te richten op de effecten van de opleidingsinspanningen op bedrijfsniveau. Daarbij is het belangrijk dat er ook aandacht wordt besteed aan de richting van de causaliteit tussen opleidingsinspanningen enerzijds en bedrijfsresultaten anderzijds, omdat nogal eens de suggestie wordt gewekt dat het voeren van een goed opleidingsbeleid een luxe is die alleen bedrijven die erg goed presteren zich kunnen permitteren.

Wanneer er een relatie wordt gevonden tussen de opleidingsinspanningen en de resultaten van het bedrijf zegt dit nog niets over een causaal verband. In het onderzoek rond de effectiviteit van het opleidingsbeleid worden vaak wel statistische verbanden gevonden tussen training en bedrijfsresultaten, maar de richting van de causaliteit komt zelden aan de orde. Een voorbeeld van dergelijk onderzoek is het onderzoek van Boon (1998) waarin bedrijfstraining gerelateerd wordt aan de productiviteit van bedrijven. Hij vindt dat bedrijfsopleidingen een statistisch significant effect hebben op de toegevoegde waarde van bedrijven. Het verband is daarmee gevonden; de richting van de causaliteit echter niet. Zoals in hoofdstuk 2 werd 
aangegeven zou het immers kunnen zijn dat bedrijfstraining de productiviteit beïnvloedt, maar het kan ook zo zijn dat een bedrijf met een hogere productiviteit meer middelen heeft voor de training van het personeel, of dat bedrijven die kampen met een lage productiviteit zich genoodzaakt voelen hun opleidingsbeleid te versterken. Overigens is het heel goed mogelijk dat er sprake is van wederzijdse positieve beïnvloeding tussen bedrijfstraining en productiviteit. Dit zou de betekenis van een goed opleidingsbeleid voor het functioneren van een bedrijf nog vergroten. In dat geval zal er een zichzelf versterkend proces kunnen ontstaan, waardoor bedrijven in een positieve spiraal terecht kunnen komen. Dit kan ook een verklaring geven voor de vaak grote verschillen tussen bedrijven voor wat betreft hun investeringen in het menselijk kapitaal van hun personeel.

Om naast de afhankelijkheid tussen bepaalde variabelen iets te kunnen zeggen over de causaliteit van statistische relaties wordt gebruik gemaakt van het begrip 'Granger-causaliteit'. Dit concept maakt het mogelijk om met behulp van tijdreeksen de richting van de causaliteit aan te duiden. In het kort gezegd omvat de methode het schatten van regressievergelijkingen waarin niet alleen de verklarende variabele gekoppeld wordt aan de te verklaren variabele, maar waar ook tijdreekselementen in de vergelijkingen opgenomen worden. Dit betekent concreet dat om de richting van de causaliteit te kunnen bepalen de volgende vergelijkingen geschat moeten worden:

$$
\begin{aligned}
\text { Prestaties }_{t} & =f\left(\text { Opleiden }_{t-1}, \text { Prestaties }_{t-1}\right) \\
\text { Opleiden }_{t} & =g\left(\text { Opleiden }_{t-1}, \text { Prestaties }_{t-1}\right)
\end{aligned}
$$

Het essentiële van dit stelsel van vergelijkingen is dat de relatie tussen opleiden en bedrijfsprestaties wordt geanalyseerd door te kijken naar het effect van opleiden in het verleden $(\mathrm{t}-1)$ en de prestaties in het verleden $(\mathrm{t}-1)$ op de huidige prestaties $(\mathrm{t})$. In de tweede vergelijking wordt de huidige opleidingsintensiteit $(t)$ gerelateerd aan de prestaties in het verleden ( $\mathrm{t}-1)$ en het opleidingsintensiteit uit het verleden ( $\mathrm{t}-1)$.

Granger (1969) stelt op basis van de schatting van dit stelsel vergelijkingen een statistische test voor op basis waarvan bepaald kan worden wat de richting van de causaliteit in een bepaalde statistisch verband is. Op basis van de Granger causaliteits test zijn er in principe vier mogelijke uitkomsten denkbaar:

1. Eenrichtingscausaliteit tussen opleidingsintensiteit en bedrijfsresultaten: De opleidingsintensiteit verklaart de bedrijfsresultaten;

2. Eenrichtingscausaliteit tussen bedrijfsresultaten en opleidingsintensiteit: De bedrijfsresultaten bepalen de opleidingsintensiteit.

3. Wederzijdse causaliteit of 'Feedback' tussen bedrijfsresultaten en opleidingsintensiteit:

Bedrijfsresultaten en opleidingsintensiteit beïnvloeden elkaar wederzijds. Wanneer er in beide gevallen sprake is van een positief effect ontstaat er een zichzelf versterkend proces;

4. Onafhankelijkheid tussen opleidingsintensiteit en bedrijfsresultaten: $\mathrm{Er}$ is geen statistisch verband tussen opleidingsintensiteit en bedrijfsresultaten. 


\section{Eerder onderzoek}

In Nederlands onderzoek werd door Bentlage et al. (1989) werd er een positief verband gevonden tussen de participatie in bedrijfsopleidingen en de financiële resultaten van het bedrijf. De factoren die de grootste invloed hadden op de prestaties van een bedrijf waren in dat onderzoek onder andere de positionering van de opleidingsfunctie binnen het bedrij $f^{10}$, de wijze waarop de informatie over kwalificaties van werknemers en functies gebruikt wordt bij het opleiden en selecteren van werknemers en de hoeveelheid opleidingen per werknemer per jaar. Bovendien kwam uit dit onderzoek naar voren dat het kort, maar wel regelmatig opleiden het meest bijdraagt aan de bedrijfsprestaties. Dit zou het geval kunnen zijn doordat er vaak het meest geleerd wordt aan het begin van de opleiding.

Voor de Nederlandse situatie is er wat recenter voor wat betreft de invloed van bedrijfsopleidingen op de productiviteit een significant effect gevonden door Gelderblom \& De Koning (1992). De Kok (2001) onderzoekt de invloed van de bedrijfsgrootte op de effectiviteit van bedrijfsopleidingen. In dit onderzoek worden de brutoproductie en de toegevoegde waarde per werknemer als productiviteitsmaatstaven gehanteerd. Er zijn volgens De Kok drie theoretische argumenten voor het bestaan van verschillende productiviteitsopbrengsten bij bedrijven van verschillende grootte: Het HRM effect, het schaaleffect en het selectie-effect. Volgens het HRM effect hangen de opbrengsten van opleidingen samen met de mate waarin bedrijven hun werknemers bij de opleidingen ondersteunen. Als er bij grote bedrijven meer sprake is van een betere ondersteuning, dan zorgt dit voor een indirect grootte-effect. Volgens het schaaleffect hebben grote bedrijven schaalvoordelen bij de organisatie van opleidingen, omdat ze meer trainingen kunnen verzorgen dan kleine bedrijven. Deze trainingen zullen ook beter afgestemd zijn op de behoeften van het bedrijf en zullen daarom ook een groter effect op de productiviteit hebben. Bij het selectie-effect gaat het om een mogelijk negatief effect van de bedrijfsomvang op het rendement van opleidingen. Wanneer het effect van opleidingen afneemt naarmate de opleidingen langer duren, zijn grotere bedrijven minder goed af, doordat juist in deze bedrijven de meeste en langst durende bedrijfsopleidingen worden gevolgd. Uit het onderzoek van De Kok komt naar voren dat er alleen sprake blijkt te zijn van een HRM-effect.

Het meeste onderzoek naar de relatie tussen opleidingsinspanningen en bedrijfsprestaties richt zicht niet primair op het verklaren van de richting van de causaliteit. Dit impliceert dat de gevonden relaties wel statistische verbanden zijn, maar geen causaal gerelateerde verschijnselen. Onderzoekers uit Singapore hebben het causaliteitsprobleem in de relatie opleiden - bedrijfsprestaties in hun analyses meegenomen (Wan et al., 2000). Uit de analyses blijkt dat bedrijven met een innovatief opleidingsbeleid beter presteren, ook wanneer er rekening gehouden wordt met de richting van de causaliteit.

10. Hiermee wordt bedoeld of er sprake is van een opleidingsapparaat in de organisatie en in hoeverre de opleidingsfunctie gerelateerd is aan de strategische doelen van de organisatie. 


\section{Gebruikte data}

Voor de schattingen is gebruik gemaakt van een databestand dat ontstaan is door twee metingen van het CBS onderzoek bedrijfsopleidingen, de jaargangen 1993 en 1999, te koppelen aan twee metingen van de productiestatistieken van dezelfde jaren. Uit het onderzoek naar bedrijfsopleidingen worden de gegevens over het HRD gehaald. De productiestatistieken worden gebruikt om gegevens over de bedrijfsprestaties te verkrijgen.

De Enquête Bedrijfsopleidingen geeft informatie over 3.549 bedrijven in 1993 en 4.017 in 1999. Wanneer deze bestanden gekoppeld worden ontstaat er een bestand met 742 bedrijven die in beide jaren aan de enquête hebben meegedaan. Op basis van de bij het CBS beschikbare databestanden worden voor wat betreft de productiestatistieken alleen de gegevens van de industrie, de groot- en detailhandel en de bouwnijverheid gebruikt. De omvang van het totaalbestand is 29.817 bedrijven in 1993 en 22.054 in 1999. Het gekoppelde productiestatistiekenbestand 1993-1999 bevat in totaal 7.105 bedrijven. Het verlies aan waarnemingen in zowel de gekoppelde productiestatistieken als in de enquête bedrijfsopleidingen heeft een aantal oorzaken. Allereerst is er bij de enquête bedrijfsopleidingen telkens sprake van een steekproef. Hierdoor kan het voorkomen dat bepaalde bedrijven maar in een enkele jaargang benaderd zijn. Daarnaast is er sprake van uitval doordat bedrijven in de periode 1993-1999 zijn opgehouden te bestaan. Ten slotte komt het voor dat bedrijven in de onderzochte periode zijn opgesplitst of gefuseerd. Hiervoor is gecorrigeerd door wanneer dat mogelijk was, afzonderlijke bedrijven die eerder of later een geheel vormen, te aggregeren tot één bedrijf. Na het koppelen van de productiestatistieken met de opleidingsgevevens ontstaat er een bestand met 229 bedrijven. Dit bestand is gebruikt om de relatie tussen opleidingsinspanningen en bedrijfsprestaties te onderzoeken. De opleidingsinspanningen worden daarbij geoperationaliseerd als het gemiddeld aantal opleidingen (zowel in- en extern) per werknemer op bedrijfsniveau. ${ }^{11}$ Voor wat betreft de bedrijfsprestaties is gebruik gemaakt van de drie in hoofdstuk 2 genoemde prestatiemaastaven, namelijk:

1. de gemiddelde winst per medewerker, gedefinieerd als de totale winst voor belastingen gedeeld door het aantal medewerkers;

2. de 'return on sales' (ROS), gedefinieerd als de totale winst voor belastingen gedeeld door de waarde van de productie of de verkopen;

3. de productiviteit per medewerker, gedefinieerd als de waarde van de verkopen gedeeld door het aantal medewerkers. ${ }^{12}$

In de analyses wordt er gecorrigeerd voor de sector waarin een bedrijf zich bevindt. In elke schatting wordt een reeks dummyvariabelen opgenomen die aangeven in welke bedrijfssector (industrie, groothandel, detailhandel of bouwnijverheid) een bedrijf zich bevindt. Deze variabelen zijn opgenomen om er voor te zorgen dat

11. Dit in tegenstelling tot de eerste analyse in dit hoofdstuk, waar er een onderscheid gemaakt wordt tussen interne en externe opleidingsinspanningen.

12. Het gaat hier dus niet om de toegevoegde waarde per werknemer, aangezien in die maatstaf ook de kosten zijn verwerkt. 
bepaalde structurele verschillen tussen de onderscheiden bedrijfssectoren (zoals bijvoorbeeld een hogere winstmarge of het onderscheid tussen productiebedrijven en verkoopbedrijven) niet verstorend kunnen werken. Daarnaast wordt er in elke analyse rekening gehouden met bedrijfsgrootte en de mate waarin het personeelsbestand gegroeid of gekrompen is. Dit om rekening te kunnen houden met eventuele verschillen die er bestaan tussen bedrijven van verschillende omvang en om ervoor te zorgen dat grote veranderingen in de personeelsomvang de analyses niet kunnen verstoren.

\section{Enkele beperkingen}

Een beperking van de analyses is dat de tijdsperiode tussen t en t-1 nogal groot is, aangezien gebruik wordt gemaakt van cijfers uit 1993 en 1999. Dit kan zowel een onderschatting als een overschatting van de effectiviteit van opleidingsinspanningen tot gevolg hebben. Wanneer de opleidingsinspanningen in 1993 het meeste opleveren in de jaren direct daarna, terwijl de opbrengsten alleen in 1999 gemeten worden, dan wordt het effect van de opleidingsinspanningen op de bedrijfsprestaties wellicht onderschat. Wanneer de opleidingsinspanningen gemeten in 1993 niet beschouwd worden als een gegeven voor een enkel jaar, maar als een patroon dat zich over verschillende jaren na 1993 voortzet, dan kan het zo zijn dat de opbrengsten van opleiden overschat worden, doordat de bedrijfsprestaties die in 1999 gemeten worden in dat geval niet alleen gerelateerd zijn aan de opleidingsinspanningen in 1993, maar ook aan de opleidingen die in de daarop volgende jaren door het personeel gevolgd werden. Een ander potentieel probleem in de empirische schattingen is dat er geen rekening gehouden kan worden met selectiviteit in het opleidingsproces. Wanneer alleen die werknemers waarbij het rendement van de opleidingen hoog is, daadwerkelijk opleidingen volgen, dan kunnen de schattingen van het opleidingsrendement, als ze geïnterpreteerd worden als geldende voor werknemers in het algemeen, te hoog uitvallen. In het kader van dit onderzoek was het niet mogelijk hier rekening mee te houden. Deze beperkingen impliceren dat de resultaten die we in de volgende paragrafen vinden met de nodige voorzichtigheid geïnterpreteerd dienen te worden. De uitkomsten mogen ook niet gezien worden als structurele indicatoren van de effectiviteit van het investeren in opleidingen, maar moeten eerder geïnterpreteerd worden als ruwe indicatoren voor de mate waarin opleidingsinspanningen en bedrijfsprestaties samenhangen.

De uitkomsten van de schattingen met betrekking tot de relatie tussen de totale opleidingsinspanningen en de bedrijfsprestaties worden in de figuren $4.3 \mathrm{t} / \mathrm{m} 4.8$ schematisch gepresenteerd. Tabel A.3 in de appendix van dit rapport geeft een overzicht van de volledige schattingsresultaten.

\section{Scholingsinspanningen en de winst per medewerker}

In figuur 4.3 wordt de relatie tussen opleidingsinspanningen en de winst per medewerker gepresenteerd. Uit de figuur komt naar voren dat de opleidingsinspanningen in 1993 een significante positieve invloed hebben op de winst per medewerker (gemeten in $€ 1.000$ ) in 1999. Het gevonden resultaat moet als volgt 
geïnterpreteerd worden: De analyse laat zien dat wanneer alle medewerkers van een bedrijf gemiddeld 1 cursus meer hebben gevolgd in het jaar 1993, dit gemiddeld genomen de winst per medewerker met rond de $€ 12.500$ verhoogt. Ook de winst van bedrijven in 1993 heeft een significante invloed op de winst in 1999. Zo geldt bijvoorbeeld dat een winst van $€ 1.000$ per medewerker in 1993 een winst van $€$ 1.243 per medewerker tot gevolg heeft. Dit impliceert dat, gemiddeld genomen, bedrijven met hoge winsten in het verleden meer kans hebben om ook later in de tijd goede resultaten te behalen. Daarentegen hebben de omvang van het bedrijf en de veranderingen in het personeelsbestand geen significante invloed op het bedrijfsresultaat.

Figuur 4.3

De relatie tussen opleiden en bedrijfsprestaties: winst per medewerker

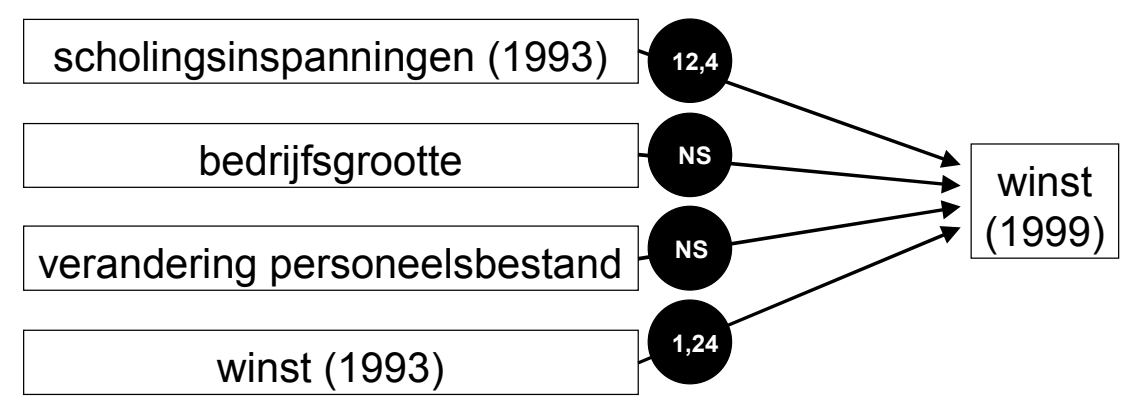

In figuur 4.4 wordt de omgekeerde relatie bekeken. Ook de bedrijfsresultaten (winst, gemeten in $€ 1.000$ ) van 1993 hebben een significant positief effect op de scholingsinspanningen per medewerker in 1999. Als de winst per medewerker $€ 1.000$ hoger ligt, doet dit het gemiddeld aantal cursussen per medewerker met 0,01 stijgen. Dit effect is erg klein in vergelijking met het effect van opleidingsinspanningen op de gemiddelde winst dat in figuur 4.3 aan de orde kwam. Daarnaast blijken de scholingsinspanningen in 1999 positief samen te hangen met de scholingsinspanningen in 1993, wat inhoudt dat bedrijven die veel aandacht besteed hebben aan opleiden in het verleden ook een grotere kans hebben om later gekenmerkt te worden door een hoge opleidingsinspanning. De omvang van het bedrijf en de veranderingen in het personeelsbestand blijken ook geen invloed te hebben op de gemiddelde scholingsinspanningen per medewerker. 
Figuur 4.4

De relatie tussen bedrijfsprestaties en opleiden: winst per medewerker

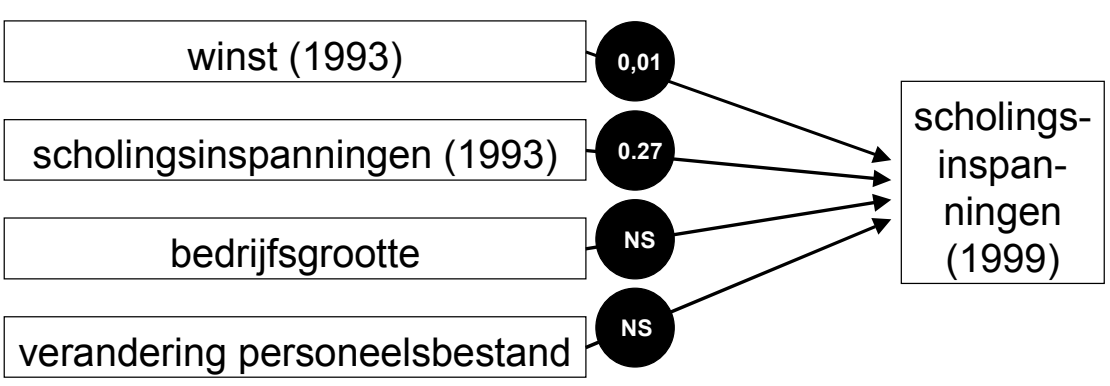

De gevonden relatie tussen de winst per medewerker en de opleidingsinspanningen is overigens een stuk kleiner dan de in figuur 4.3 besproken omgekeerde relatie. Dit kan eenvoudig worden nagegaan door het effect van een vergroting van de winst per medewerker met $€ 12.400$ op de scholingsinspanningen te berekenen. Een vergroting van de winst per medewerker met dit bedrag zal de scholingsinspanningen gemiddeld gezien met 0,124 cursussen per medewerker doen stijgen. Concreet betekent dit dat het verband tussen opleidingsinspanningen en de winst per medewerker ongeveer 8 keer zo groot is als het omgekeerde verband tussen de winst per medewerker en de opleidingsinspanningen.

Scholingsinspanningen en de 'return on sales'

Figuur 4.5 belicht de relatie tussen de opleidingsinspanningen en de return on sales (ROS). Zowel de return on sales uit 1993 als de opleidingsinspanningen in 1993 hebben een positief en significant effect op de ROS in 1999. Uit de analyses komt naar voren dat wanneer medewerkers gemiddeld 1 cursus meer volgen, dit de return on sales met $0.37 \%$ verhoogt.

Figuur 4.5

De relatie tussen opleiden en bedrijfsprestaties: Return on Sales

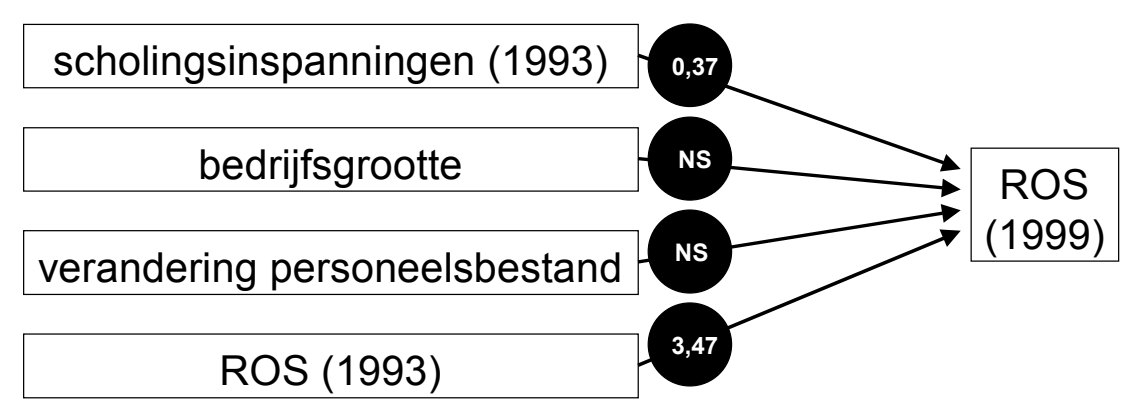




\section{Technische toelichting bij de empirische schattingen}

In de analyses van de effecten van opleidingen op bedrijfsprestaties en vice versa worden er voor iedere prestatiemaatstaf twee schattingen uitgevoerd. Voor achtereenvolgens de gemiddelde winst per medewerker, de 'return on sales' (ROS) en de productiviteit (gemiddelde verkopen per medewerker) worden de volgende vergelijkingen met behulp van OLS geschat:

$$
\begin{aligned}
& P_{t}=\alpha_{0}+\sum_{s=1}^{s} \alpha_{s} \cdot D_{s}+\beta_{1} P_{t-1}+\beta_{2} \cdot O_{t-1}+\beta_{3} \cdot G+\beta_{4} \cdot \Delta G+\varepsilon_{1} \\
& O_{t}=\delta_{0}+\sum_{s=1}^{s} \delta_{s} \cdot D_{s}+\phi_{1} O_{t-1}+\phi_{2} \cdot O_{t-1}+\phi_{3} \cdot G+\phi_{4} \cdot \Delta G+\varepsilon_{2}
\end{aligned}
$$

In de eerste vergelijking wordt de huidige bedrijfsprestatie $\left(P_{t}\right)$ verklaard door achtereenvolgens een constante, een aantal dummies voor de bedrijfssector waarin een bedrijf zich bevindt $\left(D_{s}\right)$, de opleidingsinspanning in het verleden $\left(\mathrm{O}_{\mathrm{t}-1}\right)$, de bedrijfsgrootte en de verandering in bedrijfsgrootte $(\Delta G)$. In de tweede vergelijking wordt de huidige opleidingsinspanning $\left(\mathrm{O}_{\mathrm{t}}\right)$ verklaard door de bedrijfsprestatie in het verleden, de opleidingsinspanningen in het verleden $\left(\mathrm{O}_{\mathrm{t}-1}\right)$ en verder dezelfde achtergrondvariabelen als in de eerste vergelijking.

De dummies voor de bedrijfssectoren worden in de vergelijkingen opgenomen om te corrigeren voor sectorspecifieke invloeden. In bepaalde sectoren is bijvoorbeeld de winstgevendheid structureel beter dan in andere. Hoewel zowel de bedrijfsprestaties als de opleidingsvariabelen uitgedrukt worden in eenheden per medewerker of bedrijfsvermogen (in het geval van de ROI), zou toch ook de bedrijfsgrootte op zich nog effecten kunnen hebben, bijvoorbeeld doordat schaalvoordelen de winstgevendheid beïnvloeden. Daarom is ook bedrijfsgrootte $(G)$ als correctievariable opgenomen. Tenslotte wordt de verandering in het personeelsbestand $(\Delta G)$ als verklarende variabele in de vergelijkingen opgenomen, aangezien grote veranderingen in de personeelsomvang zowel de prestaties als de deelname aan opleidingen kunnen beïnvloeden.

Uit figuur 4.6 blijkt dat de omgekeerde causaliteit tussen return on sales en scholingsinspanningen niet opgaat. De scholingsinspanningen in 1993 blijken wel samen te hangen met de scholingsinspanningen in 1999.

\section{Scholingsinspanningen en de productiviteit per medewerker}

In figuur 4.7 wordt de relatie tussen scholingsinspanningen en de productiviteit per medewerker in kaart gebracht. De productiviteit, gemeten door de gemiddelde verkopen per medewerker, blijkt significant gerelateerd te zijn aan de scholingsinspanningen. Het blijkt dat de gemiddelde productiviteit met rond de $€ 57.000$ stijgt wanneer de medewerkers van een bedrijf gemiddeld 1 cursus meer hebben gevolgd. Het gevonden bedrag is hoger dan de winsttoename als gevolg van opleidingsinspanningen, wat verklaart kan worden door de kosten die met opleidingsinspanningen gepaard gaan. Daarnaast blijkt dat een uitbreiding van het personeelsbestand ook de productiviteit per medewerker positief beïnvloedt, hoewel dit effect slechts zeer klein is. Overigens wordt het gevonden positieve effect van bedrijfsopleidingen 
ook teruggevonden in de literatuur. Voor een panel van Britse bedrijven vinden ook Dearden et al. (2000) een positief effect van bedrijfsopleidingen op de productiviteit.

Figuur 4.6

De relatie tussen bedrijfsprestaties en opleiden: Return on Sales

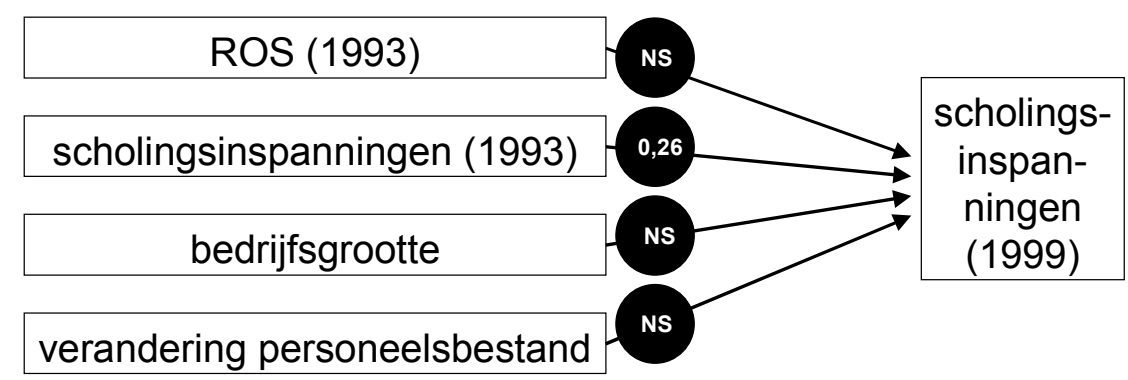

Figuur 4.7

De relatie tussen opleiden en bedrijfsprestaties: Productiviteit

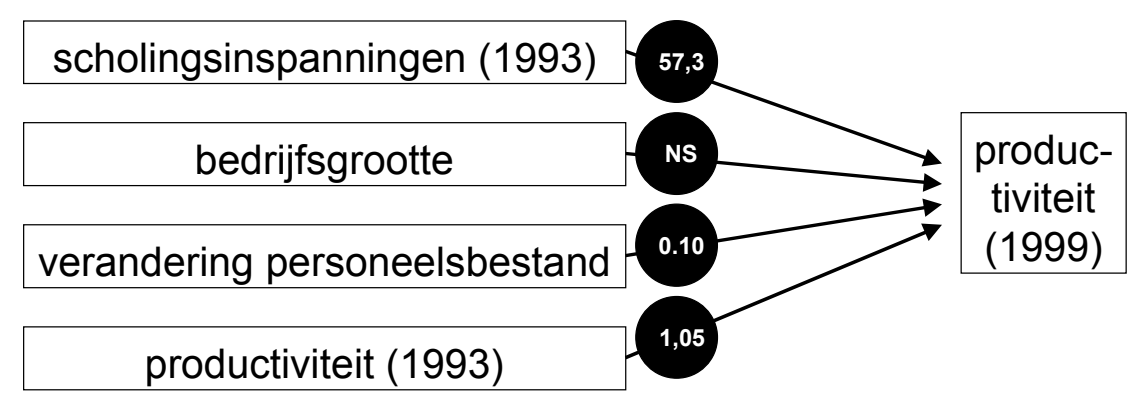

Figuur 4.8

De relatie tussen bedrijfsprestaties en opleiden: Productiviteit

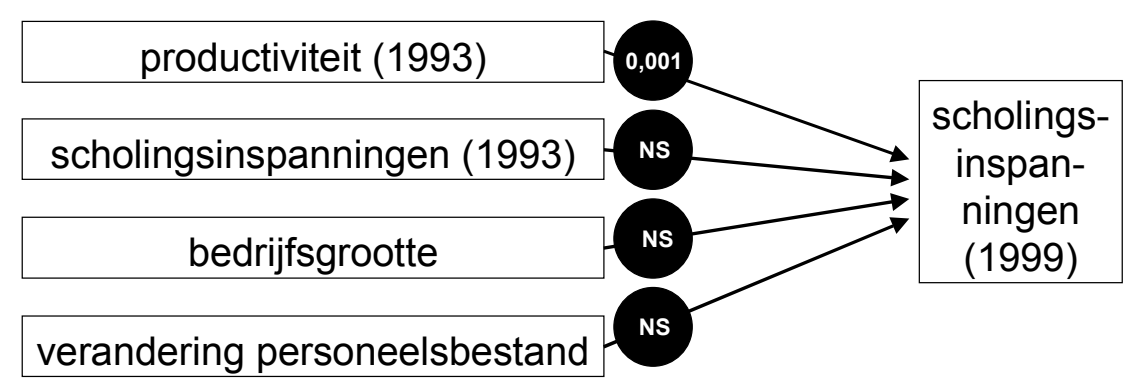

In figuur 4.8 komt de omgekeerde relatie tussen opleiden en productiviteit aan de orde. De productiviteit van een medewerker blijkt een positief effect te hebben op de scholingsinspanningen, hoewel het effect wel klein is. De analyse laat zien dat wanneer de productiviteit per medewerker $€ 1.000$ hoger ligt, dit tot gevolg heeft dat het gemiddeld aantal cursussen per medewerker met 0.001 toeneemt. Ook hier geldt 
dat dit feedback-effect minder sterk is dan het eerder gevonden effect van bedrijfsopleidingen op de productiviteit.

In tabel 4.9 worden de uitkomsten met betrekking tot de causaliteit tussen opleidingsinspanningen en bedrijfsprestaties nog eens kort samengevat. Uit de analyses blijkt daarmee dat opleidingsinspanningen een positief effect hebben op zowel de winst per medewerker, de productiviteit per medewerker en de return on sales. De gevonden relaties tussen opleiden en bedrijfsprestaties bevestigen het beeld zoals dat in de literatuur naar voren komt: het opleiden van het personeel heeft een positief effect op de prestaties van bedrijven. Ook de omgekeerde relatie tussen de bedrijfsprestaties en opleidingsinspanningen gaat op, maar de effecten zijn hier veel kleiner. Deze uitkomsten wijzen op een wederzijdse causaliteit tussen opleiden en bedrijfsprestaties.

Tabel 4.9

Gevonden causaliteit tussen opleidingsinspanningen en bedrijfsprestaties

\begin{tabular}{ll}
\hline Prestatiemaatstaf & aard van de causaliteit \\
\hline winst per medewerker & bilaterale causaliteit \\
return on sales & $\begin{array}{l}\text { eenrichtingscausaliteit tussen opleidings- } \\
\text { inspanningen en return on sales }\end{array}$ \\
productiviteit & bilaterale causaliteit
\end{tabular}

Bron: CBS (Enquête bedrijfsopleidingen en productiestatistieken)/ ROA

Voor de return on sales wordt er geen effect gevonden van de bedrijfsprestaties op de opleidingsinspanningen. Hier werkt de relatie tussen opleiden en prestaties slechts in 1 richting, namelijk van opleidingsinspanningen naar prestaties. Ten slotte blijkt dat de correctievariabelen bedrijfsgrootte en verandering in de personeelsomvang geen significant effect hebben op de scholingsinspanningen van een bedrijf.

\subsection{De korte-termijn effecten van verschillende soorten opleidingen}

In deze paragraaf wordt gekeken naar het effect dat verschillende soorten opleidingen op de prestaties van een bedrijf hebben. We kijken hier naar de effecten op de korte termijn, aangezien zowel de opleidingsinspanningen als de prestatiemaatstaven in het jaar 1999 gemeten worden. ${ }^{13}$ Wanneer de korte-termijn effecten van diverse soorten opleidingen bekeken worden, wordt er in wezen gekeken naar het saldo van twee tegengestelde effecten: ${ }^{14}$

13. Met de beschikbare data was het helaas niet mogelijk om ook naar de effecten van verschillende soorten cursussen op de langere termijn te kijken.

14. Strikt genomen wordt hier alleen de samenhang gemeten. Naast de genoemde effecten kan er dus ook sprake zijn van een positief effect van de productiviteit van het bedrijf op de cursusparticipatie. 
- $\quad$ Een positief effect op de bedrijfsprestaties doordat een bedrijf als gevolg van opleidingen over meer menselijk kapitaal beschikt;

- Een negatief effect op de bedrijfsprestaties doordat het investeren in opleidingen geld en tijd vereist.

Wanneer er op de korte termijn sprake is van een negatief effect van een bepaald soort opleidingen op de prestaties, overheerst het tweede effect. Een negatief effect op de korte termijn betekent derhalve niet dat een opleiding niet de moeite waard is. Voor sommige opleidingen valt slechts op de middellange of op de lange termijn een positief effect te verwachten. De analyses in deze paragraaf geven daarom alleen aan van welke soorten opleidingen een direct positief effect verwacht kan worden en voor welke opleidingen het korte termijn effect negatief is, wat impliceert dat dergelijke opleidingen een investering vergen die mogelijk in de toekomst terugverdiend kan worden.

Tabel 4.10

Soorten bedrijfsopleidingen en korte-termijn bedrijfsprestaties, 1999

\begin{tabular}{|c|c|c|c|c|c|c|}
\hline \multirow{2}{*}{$\begin{array}{l}\text { Opleidingen op } \\
\text { gebied van: }\end{array}$} & \multicolumn{2}{|c|}{ winst per medewerker } & \multicolumn{2}{|c|}{ return on sales } & \multicolumn{2}{|c|}{ productiviteit } \\
\hline & coëfficient & t-waarde & coëfficient & t-waarde & coëfficient & t-waarde \\
\hline Talen & 86 & 4,5 & 51 & 4,2 & 490 & 2,6 \\
\hline Verkoop en marketing & -8 & 2,5 & $-0,9$ & 0,4 & -59 & 1,8 \\
\hline Boekhouding/financiën & 25 & 0,8 & 14,7 & 0,7 & 282 & 0,9 \\
\hline Management & 43 & 4,9 & 7,6 & 1,4 & 196 & 2,3 \\
\hline Kantoorwerk & 20 & 0,7 & 2,5 & 0,1 & 36 & 0,1 \\
\hline Persoonlijke vaardigh. & 1 & 0,2 & $-2,4$ & 1,1 & 66 & 2,0 \\
\hline Informatica & -58 & 3,7 & $-25,7$ & 2,6 & -1 & 0,0 \\
\hline Techniek & 9 & 3,3 & 0,8 & 0,5 & 92 & 3,6 \\
\hline Milieu/arbo & 1 & 0,6 & $-0,7$ & 0,6 & 39 & 2,2 \\
\hline Diensten & 9 & 1,5 & 3,4 & 0,9 & 84 & 1,4 \\
\hline Anders & -3 & 0,2 & 2,1 & 0,2 & -28 & 0,2 \\
\hline $\bar{R}^{2}$ & 0,094 & & 0,029 & & $\begin{array}{l}0.14 \\
1137\end{array}$ & \\
\hline Aantal waarnemingen & 1137 & & 1137 & & 1137 & \\
\hline
\end{tabular}

Bron: CBS (Enquête bedrijfsopleidingen en productiestatistieken)/ ROA

In tabel 4.10 wordt een overzicht gegeven van de effecten van verschillende soorten opleidingen op de bedrijfsprestaties. In de tabel worden de significante coëfficiënten aangeduid met een grijze achtergrond. Het valt allereerst op dat voor talencursussen een sterk positief effect hebben op alle prestatiemaatstaven. Blijkbaar zorgt dit soort cursussen voor direct bruikbare competenties die de zowel omzet als de winst per medewerker positief beïnvloeden. Verkoop en marketing cursussen hebben op de korte termijn daarentegen een negatief effect op de winst en de productiviteit per medewerker, wat inhoudt dat de kosten de opbrengsten op de korte termijn overstijgen. Management cursussen hebben daarentegen wel een positief korte termijn effect. Blijkbaar zorgen dergelijke cursussen voor een snelle verbetering van de beschikbare managementcompetenties, die ook op de korte termijn al resulteren in betere bedrijfsprestaties. 
Bedrijfsopleidingen op het gebied van persoonlijke vaardigheden en milieu en arbeidsomstandigheden hebben ook een positief effect op de gemiddelde productiviteit van een bedrijf. Voor informatica-opleidingen geldt daarentegen dat ze op de korte termijn minder opbrengen dan de investeringen die ermee gemoeid zijn. De opbrengsten van dergelijke opleidingen volgen mogelijk later. Ten slotte blijkt dat opleidingen op het gebied van techniek wel een positief korte-termijn effect hebben. Deze vakgerichte cursussen zorgen waarschijnlijk voor competenties die direct in het werk toegepast kunnen worden waardoor ze de productiviteit en de winst per werknemer positief beïnvloeden.

\subsection{Conclusies}

In dit hoofdstuk is allereerst de relatie tussen bepaalde tot het HRD-beleid behorende instrumenten, zoals bijvoorbeeld het hebben van een opleidingsplan, en de deelname van de medewerkers aan interne en externe bedrijfsopleidingen, aan de orde gekomen. Uit de analyses blijkt dat de deelname aan bedrijfsopleidingen positief beïnvloed worden door deze HRD-instrumenten, waarbij overigens wel opvalt dat er verschillen zijn tussen in- en externe bedrijfopleidingen.

In het tweede gedeelte van het hoofdstuk is ingegaan op de vraag in hoeverre ook aangetoond kan worden dat het opleiden van het personeel voor bedrijven lonend is. Met behulp van een panel van Nederlandse bedrijven is de opleidingsinspanning gerelateerd aan de bedrijfsprestaties. Uit de analyses blijkt dat voor alle gebruikte prestatiemaatstaven, de bedrijfsprestaties significant verband houden met de opleidingsinspanningen. Daarnaast blijkt dat er ook een omgekeerde relatie geldt, hoewel deze minder sterk is. Dit geeft aan dat bedrijven door in hun personeel te investeren in een positieve spiraal terecht kunnen komen waarin zowel de opleidingsinspanningen als de bedrijfsresultaten blijven toenemen. Opleiden blijkt dus voor Nederlandse bedrijven lonend te zijn. 



\section{Literatuur}

Bentlage, F. A., Van Duren, J. A. A., Franso, L., Van Hooft, P. L. R. M., \& Smit, G. J. P. (1989), Winst op Eigen Scholing, Resultaten van een Onderzoek naar de Relatie tussen Opleidingsinspanningen en Bedrijfsprestatie in Nederland (Vol. projectnummer 2414), Den Haag: Ministerie van Sociale Zaken en Werkgelegenheid.

Boon, M. (1998), Employee Training in Dutch Manufacturing: CBS.

De Grip, A. (2001), Dynamiek op de arbeidsmarkt en de employability van werkenden. Tijdschrift voor Arbeidsvraagstukken, 17(3), 213-221.

De Kok, J. (2001), De Opbrengsten van Bedrijfsopleidingen: Waarom de Opbrengsten van een Extra Opleidingsdag voor Grotere Bedrijven Hoger Zijn Dan voor Kleinere Bedrijven, Zoetermeer: EIM.

Dearden, L., Reed, H., \& Van Reenen, J. (2000), Who Gains When Workers Train? Training and Corporate Productivity in a Panel of British Industries (Working Paper WP 00/04), London: Institute for Fiscal Studies.

Dekker, R., De Grip, A., \& Heijke, H. (2002), The Effects of Training and Overeducation on Career Mobility in a Segmented Labour Market. International Journal of Manpower, 23(2), 106-125.

Erickson, C. L., \& Jacoby, S. M. (2002), The Effect of Employer Networks on Workplace Innovation and Training. Los Angeles, CA: UCLA Anderson School of Management.

Gelderblom, A., \& De Koning, J. (1992), Meer-Jarig, Minder-Waardig? Een Onderzoek naar de Invloed van Leeftijd op Productiviteit en Beloning (OSA Voorstudie V39), Den Haag: NEI.

Granger, C. W. J. (1969), Investigating Causal Relations by Econometric Models and CrossSpectral Methods, Econometrica, 424-438.

Green, F., Ashton, D., Burchell, B., Davies, B., \& Felstead, A. (2000), Are British Workers Becoming More Skilled? In L. Borghans \& A. De Grip (Eds.), The Overeducated Worker?, The Economics of Skill Utilization (pp. 77-106), Cheltenham: Edward Elgar.

Huselid, M. A., Jackson, S. E., \& Schuler, R. S. (1997), Technical and Strategic Human Resource Management Effectiveness as Determinants of Firm Performance, Academy of Management Journal, 40(1), 171-188.

Paauwe, J., \& Richardson, R. (1997), Introduction: Special Issue on HRM and Performance. International Journal of Human Resource Management, 3(8), 257-262.

ROA (2000), Werkgelegenheid en Scholing 1999 (ROA Rapport ROA-R-2000/5), Maastricht: Researchcentrum voor Onderwijs en Arbeidsmarkt.

Rothwell, W. J. (1996), Beyond Training and Development, State-of-the-Art Strategies for Enhancing Human Performance, New York: AMACOM.

Swanson, R. A. (2001), Assessing the Financial Benefits of Human Resource Development, Cambridge MA: Perseus Publishing.

Thijssen, J. G. L. (1997), Leren om te Overleven, over Personeelsontwikkeling als Permanente Educatie in een Veranderende Arbeidsmarkt, Bilthoven: Oratie.

Wan, T. W. D., Ong, C. H., \& Kok, C. F. V. (2000), Organisational Strategy, Strategic HRM and Firm Performance: A Structural Equation Modelling (SEM) Approach.Unpublished manuscript, Singapore.

Zwick, T. (2002), Training and Firm Productivity: Panel Evidence for Germany (SKOPE Research Paper 23), Oxford, UK: SKOPE. 



\section{Appendix: Statistische Analyses}

Tabel A.1

De relatie tussen HRM instrumenten en intern opleiden van het personeel, 1999

\begin{tabular}{|c|c|c|}
\hline \multirow[t]{2}{*}{ Variabele } & \multicolumn{2}{|c|}{$\begin{array}{l}\text { opleidingen per } \\
\text { medewerker }\end{array}$} \\
\hline & coëfficient & t-waarde \\
\hline Constante term & 0,029 & \\
\hline Systematisch vaststellen behoefte organisatie & 0,015 & 4,1 \\
\hline Systematisch vaststellen behoefte individuele werknemers & 0,079 & 3,1 \\
\hline Beschikking over een opleidingsbudget & 0,043 & 1,7 \\
\hline Beschikking over een opleidingsplan & 0,124 & 4,9 \\
\hline Beschikking over een opleidingscentrum & 0,431 & 14,5 \\
\hline Collectieve opleidingsafspraken & 0,065 & 2,7 \\
\hline $\begin{array}{l}\bar{R}^{2} \\
\text { Aantal waarnemingen }\end{array}$ & $\begin{array}{l}0,121 \\
4016\end{array}$ & \\
\hline
\end{tabular}

Bron: CBS (Enquête bedrijfsopleidingen)/ ROA

Tabel A.2

De relatie tussen HRM instrumenten en extern opleiden van het personeel, 1999

\begin{tabular}{lrr} 
Variabele & \multicolumn{2}{c}{$\begin{array}{c}\text { opleidingen per } \\
\text { medewerker } \\
\text { t-waarde } \\
\text { coëfficient }\end{array}$} \\
\hline Constante term & 0,241 & \\
Systematisch vaststellen behoefte organisatie & $-0,008$ & 0,4 \\
Systematisch vaststellen behoefte individuele werknemers & 0,101 & 4,6 \\
Beschikking over een opleidingsbudget & 0,139 & 6,6 \\
Beschikking over een opleidingsplan & 0,065 & 3,0 \\
Beschikking over een opleidingscentrum & $-0,030$ & 1,0 \\
Collectieve opleidingsafspraken & 0,143 & 7,1 \\
$\bar{R}^{2}$ & & \\
Aantal waarnemingen & 0,062 & \\
\hline
\end{tabular}

Bron: CBS (Enquête bedrijfsopleidingen)/ ROA 
Tabel A. 3

De relatie tussen opleidingsinspanningen van bedrijven en hun performance, 1993-1999

\begin{tabular}{|c|c|c|c|c|c|c|}
\hline \multirow{2}{*}{$\begin{array}{l}\text { Variabele } \\
\text { Opleiding -> performanc }\end{array}$} & \multicolumn{2}{|c|}{$\begin{array}{l}\text { winst per medewerker } \\
\text { coëfficient t-waarde }\end{array}$} & \multicolumn{2}{|c|}{$\begin{array}{l}\text { return on sales } \\
\text { coëfficient } t \text {-waarde }\end{array}$} & \multicolumn{2}{|c|}{$\begin{array}{c}\text { productiviteit } \\
\text { coëfficient t-waarde }\end{array}$} \\
\hline & 999 & & & & & \\
\hline $\begin{array}{l}\text { Performance } 1993 \\
\text { Opleiding } 1993 \\
\text { Bedrijfsgrootte } \\
\text { Verandering }\end{array}$ & $\begin{array}{r}€ 1,242 \\
€ 12.384 \\
€ 990,0\end{array}$ & $\begin{array}{r}15,3 \\
3,6 \\
0,7\end{array}$ & $\begin{array}{r}0,367 \% \\
1,497 \% \\
0,00 \%\end{array}$ & $\begin{array}{l}6,5 \\
1,9 \\
0,1\end{array}$ & $\begin{array}{r}€ 1,054 \\
€ 57.292 \\
€ 5,0\end{array}$ & $\begin{array}{r}24,1 \\
3,0 \\
0,6\end{array}$ \\
\hline personeelsomvang & $€ 100$ & 1,4 & $-0.003 \%$ & 1,1 & $€ 103,0$ & 1,9 \\
\hline $\begin{array}{l}\bar{R}^{2} \\
\text { Aantal waarnemingen }\end{array}$ & $\begin{array}{r}0,533 \\
228\end{array}$ & & $\begin{array}{r}0,184 \\
228\end{array}$ & & $\begin{array}{r}0,767 \\
228\end{array}$ & \\
\hline \multicolumn{7}{|c|}{ Performance -> opleiding 1999} \\
\hline $\begin{array}{l}\text { Performance } 1993 \\
\text { Opleiding } 1993 \\
\text { Bedrijfsgrootte } \\
\text { Verandering } \\
\text { personeelsomvang }\end{array}$ & $\begin{array}{r}0,01 \text { opl } \\
0,272 \text { opl } \\
-0,00 \text { opl } \\
-0.00 \text { opl }\end{array}$ & $\begin{array}{l}3,7 \\
2,3 \\
0,1\end{array}$ & $\begin{array}{r}0,011 \text { opl } \\
0,258 \mathrm{opl} \\
0,00 \mathrm{opl}\end{array}$ & $\begin{array}{l}1,3 \\
2,1 \\
0,1\end{array}$ & $\begin{array}{r}0,0008 \mathrm{opl} \\
0,18 \mathrm{opl} \\
0,00 \mathrm{opl} \\
-0,00 \mathrm{opl}\end{array}$ & $\begin{array}{l}2,9 \\
1,5 \\
0,3\end{array}$ \\
\hline $\begin{array}{l}\bar{R}^{2} \\
\text { Aantal waarnemingen }\end{array}$ & $\begin{array}{r}0,083 \\
228\end{array}$ & & $\begin{array}{r}0,034 \\
228\end{array}$ & & $\begin{array}{r}0,062 \\
228\end{array}$ & \\
\hline
\end{tabular}

Bron: CBS (Enquête bedrijfsopleidingen en productiestatistieken)/ ROA 